ఠ

\title{
Hyaluronic acid-functionalized bismuth oxide nanoparticles for computed tomography imaging-guided radiotherapy of tumor
}

This article was published in the following Dove Press journal:

International Journal of Nanomedicine

21 August 2017

Number of times this article has been viewed

\author{
Fengyi Du ${ }^{1,2, *}$ \\ Jiaming Lou ${ }^{1, *}$ \\ Rong Jiang ${ }^{2, *}$ \\ Zhengzou Fang ${ }^{2, *}$ \\ Xuefen Zhao ${ }^{2}$ \\ Yuanyuan $\mathrm{Niu}^{2}$ \\ Shenqiang Zou ${ }^{3}$ \\ Miaomiao Zhang ${ }^{2}$ \\ Aihua Gong ${ }^{2}$ \\ Chaoyang $\mathrm{Wu}^{\prime}$ \\ 'Department of Oncology, The \\ Affiliated People's Hospital, Jiangsu \\ University, Zhenjiang, People's \\ Republic of China; 'Department of \\ Cellular Biology, School of Medicine, \\ Jiangsu University, Zhenjiang, People's \\ Republic of China; ${ }^{3}$ Department \\ of Hepatosis, The Third Hospital \\ of Zhenjiang Affiliated, Jiangsu \\ University, Zhenjiang, People's \\ Republic of China \\ *These authors contributed equally \\ to this work
}

\begin{abstract}
The inherent radioresistance and inaccuracy of localization of tumors weaken the clinical implementation effectiveness of radiotherapy. To overcome these limitations, hyaluronic acid-functionalized bismuth oxide nanoparticles ( $\mathrm{HA}-\mathrm{Bi}_{2} \mathrm{O}_{3} \mathrm{NPs}$ ) were synthesized by one-pot hydrothermal method for target-specific computed tomography (CT) imaging and radiosensitization of tumor. After functionalization with hyaluronic acid, the $\mathrm{Bi}_{2} \mathrm{O}_{3} \mathrm{NPs}$ possessed favorable solubility in water and excellent biocompatibility and were uptaken specifically by cancer cells overexpressing CD44 receptors. The as-prepared $\mathrm{HA}-\mathrm{Bi}_{2} \mathrm{O}_{3} \mathrm{NPs}$ exhibited high X-ray attenuation efficiency and ideal radiosensitivity via synergizing X-rays to induce cell apoptosis and arrest the cell cycle in a dose-dependent manner in vitro. Remarkably, these properties offered excellent performance in active-targeting CT imaging and enhancement of radiosensitivity for inhibition of tumor growth. These findings demonstrated that $\mathrm{HA}-\mathrm{Bi}_{2} \mathrm{O}_{3} \mathrm{NPs}$ as theranostic agents exhibit great promise for $\mathrm{CT}$ imaging-guided radiotherapy in diagnosis and treatment of tumors.
\end{abstract}

Keywords: $\mathrm{HA}-\mathrm{Bi}_{2} \mathrm{O}_{3} \mathrm{NPs}, \mathrm{CT}$ imaging, radiosensitivity, HA, bismuth

\section{Introduction}

Radiotherapy has been extensively applied in cancer therapy except for surgery and chemotherapy. This technique employs high-energy X-rays and involves deposition of irradiation doses in tumor sites by causing free radical damage or DNA damage. ${ }^{1-4}$ However, poor radiosensitivity or inherent radioresistance of tumors leads to utilization of higher irradiation doses for effective elimination of cancer cells; this radioresistance is caused by various mechanisms (eg, hypoxic, S-phase) which may finally limit the clinical implementation of radiotherapy. Besides, inaccuracy of tumor localization and poor discrimination between lesion and tumor-surrounding tissues lead to inadequate dose coverage to the lesion tissues and overexposure to normal tissues, ${ }^{5}$ which results in the occurrence of irradiation side effects and failure of tumor control as well as cancer recurrence. Therefore, development of a new effective way for enhancing tumor radiosensitivity while minimizing systemic side effects becomes an urgent strategy. In this aspect, combining chemotherapy and radiotherapy is a well-established technique for radiosensitization. The newly developed theranostic formulations offer several advantages including assessment of biodistribution and noninvasive accumulation of drugs at target sites, visualization of drug distribution and drug release at the target site, optimization of formulation which relies on triggered drug release, and real-time monitoring of the therapeutic responses with the help of different kinds of imaging modalities. ${ }^{6}$
Correspondence: Chaoyang Wu Department of Oncology, The Affiliated People's Hospital, Jiangsu University, Dianli Road, Zhenjiang 2I 2002, People's Republic of China Email wuchaoyang9@।63.com 
In recent years, nanotechnology has been considered as an attractive strategy for cancer diagnostics and therapy owing to its multifunctional applications in tumor-targeted drug delivery and drug localization..$^{7-12}$ Additionally, nanoparticles (NPs) could be ideal candidates for accurate tumor-targeting imaging to locate tumors because of their prolonged circulation time, selective accumulation in tumors by the enhanced permeability and retention effect, and active targeting through conjugating with folic acid, antibodies, peptides, or hyaluronic acid (HA). ${ }^{13}$ In addition, the X-ray dose of the surrounding tissue will be greatly reduced, and higher dose can be concentrated at the tumor region containing NPs. Interestingly, NPs were designed to serve as radiosensitization enhancers. ${ }^{14-16}$ Heavy metal (with high- $Z$ elements such as $\mathrm{Au}, \mathrm{Pt}, \mathrm{Bi}, \mathrm{Ta}, \mathrm{Gd}$, and $\mathrm{Lu}^{17,18}$ ) NPs as promising computed tomography (CT) contrast agents (CAs) could be used in radiosensitizing therapy because of their high X-ray photon capture cross-section and compton scattering effect. When X-rays interact with high-Z NPs, Auger electrons and photoelectrons are emitted, with diameters ranging from nanometers to several micrometers. Furthermore, when photon beams of kilovolt and megavolt energy interact with high- $Z$ NPs in a tumor, the release of secondary electrons can injure tumor cells, leading to a higher treatment efficacy than radiation alone.

CT is a mainstay of clinical diagnostic modality with the advantages of high resolution, no depth limitation, and possibility of three-dimensional reconstruction. However, pharmacokinetic limitations of clinically available CT CAs (small iodinated molecules), including short circulation half-lives and nonspecific distribution, are the main causes of CT failure for tumor-targeting imaging and angiography. Moreover, various intrinsic limitations of CT imaging particularly with respect to inadequate soft tissue contrast, low-throughput capacity, limited accessibility, and ionizing radiation are also considered as notable hurdles that prevent the application of CT for clinical diagnosis. ${ }^{19}$

To date, bismuth-based NPs (BiNPs) such as $\mathrm{Bi}_{2} \mathrm{~S}_{3}$ nanodots ${ }^{20-22}$ and $\mathrm{Bi}_{2} \mathrm{Se}_{3}$ nanoplates ${ }^{23}$ have been employed as CT CAs which are commonly used in clinical imaging. Moreover, BiNPs have received wide attention in the field of radiotherapy research due to their remarkable radiation dose enhancement under kilovolt-energy X-ray beams, which is significantly higher than the well-known gold radiation sensitizer. ${ }^{24}$ As a direct thin-band-gap n-type semiconductor (1.3 eV), $\mathrm{Bi}_{2} \mathrm{~S}_{3}$ NPs with high near-infrared (NIR) absorption coefficient have been used as NIR absorbers to extend the absorption wavelength to the NIR region for the improvement of solar-harnessing capability of solar cells. ${ }^{25-28}$ Encouraged by the ideal NIR absorption property of BiNPs, it is very much possible to use them as CT agents, which thus makes them a simple but powerful precision nanomedicine that comprises only $\mathrm{Bi}_{2} \mathrm{O}_{3}$ NPs without any additional functional components that can be used to simultaneously achieve CT bimodal imaging. However, it has been suggested that the significant radiosensitization effect of $\mathrm{Bi}_{2} \mathrm{~S}_{3}$ NPs could be successfully realized through their inhibition effect on tumor growth in a tumor-bearing mice model, where intrinsic potential biological toxicity of sulfur element could not be ignored. ${ }^{29}$ Furthermore, as we have known, the lower cost of bismuth element and higher radiation dose enhancement ${ }^{30,31}$ compared to gold element could make the BiNP a better candidate for further commercial use. Thus, it is suggested that $\mathrm{Bi}_{2} \mathrm{O}_{3} \mathrm{NP}$ can be used as an ideal alternative to evaluate the therapeutic effect of nanomedicine-based radiosensitizers in the interstitial radiotherapy research.

HA is a naturally linear polysaccharide and a major ligand due to its biocompatible, nontoxic, biodegradable, and non-immunogenic advantages. As a target-specific drug delivery carrier, HA has been investigated well in the HA receptor-mediated endocytosis because of its polyanionic characteristics and hydrophilicity, ${ }^{32}$ and highly efficient targeted delivery to target sites with HA receptors, such as CD44, HARE, and LYVE-1, for various biological functions. ${ }^{33,34}$

According to over-mentioned intensive reports, we chose $\mathrm{HA}$ as a targeting ligand to synthesize the $\mathrm{HA}-\mathrm{Bi}_{2} \mathrm{O}_{3} \mathrm{NPs}$ as a multifunctional theranostic platform that can afford spatialand temporal-specific CT imaging and enable overcoming cancer radioresistance. This specifically developed tumortargeted probe holds a great promise as a CT imaging CA with better CT imaging quality at reduced CA dosage when compared with the currently available CAs imaged using a clinical CT scanner. In order to exploit the attractive features of Bi element and that of multifunctional NPs, we evaluated the radiosensitizing effect of $\mathrm{HA}-\mathrm{Bi}_{2} \mathrm{O}_{3} \mathrm{NPs}$ in hepatoma cells in vitro and tumor-bearing female mice model in vivo.

\section{Materials and methods Materials}

Fluorescein diacetate (FDA) and propidium iodide (PI) were purchased from Sigma (St Louis, MO, USA). $\mathrm{BiCl}_{3} \cdot 6 \mathrm{H}_{2} \mathrm{O}$ and diethylene glycol $(99 \%)$ were acquired from Hengrui Pharmaceutical Co., Ltd (Lianyungang, People's Republic of China). 3-(4,5-Dimethyl-thiazol-2-yl)-5-(3-carbo xymethoxyphenyl)-2-(4-sulfophenyl)-2H-tetrazolium (MTS) was purchased from Promega (Cell Titer Aqueous One Solution Cell Proliferation Assay kit; Madison, WI, USA). 
$\mathrm{NaH}_{2} \mathrm{PO}_{4}, \mathrm{Na}_{2} \mathrm{HPO}_{4}$, and $\mathrm{H}_{2} \mathrm{SO}_{4}$ were obtained from Guangfu Fine Chemical Research Institute (Tianjin, People's Republic of China). Fetal bovine serum and Dulbecco's Modified Eagle's Medium (DMEM) were purchased from Invitrogen China Limited (Shanghai, People's Republic of China). All chemicals were of analytical grade and were utilized without further purification.

\section{Synthesis of $\mathrm{HA}-\mathrm{Bi}_{2} \mathrm{O}_{3} \mathrm{NPs}$}

The HA- $\mathrm{Bi}_{2} \mathrm{O}_{3}$ NPs were prepared using a slightly modified procedure of the "polyol" method developed by Petoral et al. ${ }^{35}$ Specifically, $5.7 \mathrm{mmol} \mathrm{BiCl}_{3}$ was dissolved in $30 \mathrm{~mL}$ of diethylene glycol (DEG) and constantly stirred to form a transparent viscous solution. The solution was heated in a silicon oil bath at $140^{\circ} \mathrm{C}-160^{\circ} \mathrm{C}$ for $1 \mathrm{~h}$. Then, $7.5 \mathrm{mmol}$ $\mathrm{NaOH}$ dissolved in $30 \mathrm{~mL}$ of DEG was added. After complete dissolution of the reactants, the solution was refluxed at $180^{\circ} \mathrm{C}$ for $30 \mathrm{~min}$ under vigorous stirring. The prepared NPs were cooled to room temperature. Subsequently, $0.5 \mathrm{mmol}$ $\mathrm{HA}$ and $0.5 \mathrm{mmol} \mathrm{NaOH}$ were added. The solution was then refluxed at room temperature for $6 \mathrm{~h}$ under strong stirring, yielding a white precipitate. After the system was cooled to room temperature naturally, the transparent suspension was filtered with a $0.22-\mu \mathrm{m}$ membrane to remove any large-sized agglomerates. The prepared solution was then dialyzed against water for 3 days in a $14-\mathrm{kDa}$ molecular weight cutoff dialysis bag. The dialysis solution was collected and freeze-dried using a vacuum freeze dryer. Thus, $\mathrm{HA}-\mathrm{Bi}_{2} \mathrm{O}_{3}$ NPs powders were obtained and stored for further characterization.

\section{Instrumentation and characterizations}

The chemical structures of $\mathrm{HA}-\mathrm{Bi}_{2} \mathrm{O}_{3} \mathrm{NPs}$ were analyzed using a Fourier transform infrared (FT-IR) spectrometer (Nicolet Nexus 470; GMI, Franklin, IN, USA). The elemental composition was determined by elemental analysis performed using X-ray photoelectron spectroscopy (XPS). The resultant particle sizes were analyzed by a NanoDLS particle size analyzer (Brookhaven Instruments Corporation, Holtsville, $\mathrm{NY}$, USA). The morphologies of the $\mathrm{HA}-\mathrm{Bi}_{2} \mathrm{O}_{3} \mathrm{NPs}$ were examined by high-resolution transmission electron microscopy (HRTEM) on a JEM-2100 microscope (JEOL, Tokyo, Japan) under an accelerating voltage of $200 \mathrm{kV}$. Ultravioletvisible (UV-Vis) absorption spectra were recorded using a UV-2450 UV-Vis spectrophotometer (Shimadzu, Kyoto, Japan). Photoluminescence emission measurement was made using a Cary Eclipse Fluorometer (Varian, Palo Alto, CA, USA). The bismuth element of $\mathrm{HA}-\mathrm{Bi}_{2} \mathrm{O}_{3}$ NPs was quantified by linear calibration using amounts of potassium iodine previously determined by inductively coupled plasma mass spectroscopy (ICP-MS).

\section{Cellular binding and uptake tests}

For cellular binding and uptake analysis, each cell line $\left(1 \times 10^{6}\right.$ cells $)$ was treated with phosphate-buffered saline (PBS) ( $\mathrm{pH} 7.4$ ) containing $2 \%$ bovine serum albumin at $4{ }^{\circ} \mathrm{C}$ for $30 \mathrm{~min}$. The cells were then washed three times with PBS (pH 7.4), followed by an incubation with fluorescein isothiocyanate (FITC)-labeled $\mathrm{HA}-\mathrm{Bi}_{2} \mathrm{O}_{3}$ NPs $(5 \mathrm{mg} / \mathrm{mL})$ at $37^{\circ} \mathrm{C}$ for $6 \mathrm{~h}$. To remove unbound NPs, the cells were washed three times with and resuspended in PBS ( $\mathrm{pH} 7.4)$. The cellular binding of $\mathrm{HA}-\mathrm{Bi}_{2} \mathrm{O}_{3} \mathrm{NPs}$ was analyzed using flow cytometry on a FACS calibur cytometer (BD Accuri ${ }^{\mathrm{TM}}$ C6; BD Biosciences, Becton, Dickinson and Company, Franklin Lakes, NJ, USA). In order to observe the effect of free HA on cellular uptake, the cells were also treated with free $\mathrm{HA}(5 \mathrm{mg} / \mathrm{mL})$ at $37^{\circ} \mathrm{C}$ for $1 \mathrm{~h}$, prior to their incubation with FITC-labeled HA- $\mathrm{Bi}_{2} \mathrm{O}_{3}$ NPs.

\section{Cell viability assay of the $\mathrm{HA}-\mathrm{Bi}_{2} \mathrm{O}_{3} \mathrm{NPs}$}

The cytotoxicity of $\mathrm{HA}-\mathrm{Bi}_{2} \mathrm{O}_{3}$ NPs was evaluated in T/G HAVSMC (aorta/smooth muscle, ATCC ${ }^{\circledR}$ number: CRL-1999), MCF7 (mammary gland, breast, derived from metastatic site: pleural effusion, ATCC ${ }^{\circledR}$ number: HTB-22 ${ }^{\mathrm{TM}}$ ), and SMMC7721 (human hepatocarcinoma, ATCC ${ }^{\circledR}$ number: HB-8065) cells using the MTS assay according to the protocol supplied by the manufacturer. Briefly, these cells were seeded in a 96-well plate at a density of $3 \times 10^{3}$ cells $/$ well $^{36}$ and incubated for $24 \mathrm{~h}$ at $37^{\circ} \mathrm{C}$ and $5 \% \mathrm{CO}_{2}$, and then the growth medium was replaced with DMEM containing different concentrations of $\mathrm{HA}-\mathrm{Bi}_{2} \mathrm{O}_{3}$ NPs. Each sample was prepared in triplicate. After incubation for $24 \mathrm{~h}, 20 \mu \mathrm{L}$ MTS solution was added to each well and incubated for $3 \mathrm{~h}$ at $37^{\circ} \mathrm{C}$ under $5 \%$ $\mathrm{CO}_{2}$. The absorbance of each well was measured at $490 \mathrm{~nm}$ using Synergy HT Multi-Mode Microplate Reader (BioTek, Winooski, VT, USA). Non-seeded wells (containing only DMEM) were used as zero sitting, non-treated cells (in DMEM) were used as control, and the relative cell viability (mean $\pm \mathrm{SD}, \mathrm{n}=3$ ) was expressed as (Abs sample - Abs zero sitting $) /($ Abs control - Abs zero sitting $) \times 100 \%$.

\section{Hemolysis assay}

All animal experiments in this study were executed according to the protocol approved by the Management Rules of the Ministry of Health of the People's Republic of China and approved by the Institutional Animal Care and Use Committee of Jiangsu University. Hemolysis assay was carried out in accordance with the procedure reported in 
the literature ${ }^{37-39}$ with slight modification. In brief, fresh mouse blood stabilized with heparin sodium was kindly prepared. The blood was centrifuged (1,200 rpm, $15 \mathrm{~min})$ to remove supernatant, washed with PBS five times to completely remove serum, and obtain the mouse red blood cells (MRBCs). Thereafter, the diluted MRBC suspension $(0.1 \mathrm{~mL})$ was transferred into $2 \mathrm{~mL}$ tubes prefilled with $0.9 \mathrm{~mL} \mathrm{ddH}_{2} \mathrm{O}$ (as positive control), $0.9 \mathrm{~mL}$ PBS (as negative control), and $0.9 \mathrm{~mL}$ PBS containing $\mathrm{HA}-\mathrm{Bi}_{2} \mathrm{O}_{3} \mathrm{NPs}$ with different particle concentrations $(25-800 \mu \mathrm{g} / \mathrm{mL})$, respectively. The mixtures were incubated for $2 \mathrm{~h}$ at $37^{\circ} \mathrm{C}$ after gentle shaking and centrifuged at 12,000 rpm for $1 \mathrm{~min}$. Finally, the photographs of the samples were taken, and the absorbance of the supernatants (hemoglobin) was measured by a UV-2450 UV-Vis spectrophotometer. The hemolysis percentages of different samples were calculated by dividing the difference in absorbance at $541 \mathrm{~nm}$.

\section{Histological analysis}

Mice were sacrificed 30 days after intravenous injection of $\mathrm{HA}-\mathrm{Bi}_{2} \mathrm{O}_{3} \mathrm{NPs}$ at a dose of $40 \mathrm{mg} / \mathrm{kg}$, and mice without the injection of $\mathrm{HA}-\mathrm{Bi}_{2} \mathrm{O}_{3} \mathrm{NPs}$ were used as control. Susceptible tissues (heart, spleen, liver, lung, and kidney) were harvested from the above two groups (control and test groups). The organs were immersed in 4\% paraformaldehyde for $24 \mathrm{~h}$ at $4^{\circ} \mathrm{C}$, dehydrated, and treated for inclusion in paraffin. The specimen was sectioned serially at 4-mm thickness, stained with hematoxylin and eosin, and observed under an optical microscope.

\section{Biodistribution of $\mathrm{HA}-\mathrm{Bi}_{2} \mathrm{O}_{3} \mathrm{NPs}$ in vivo}

To study the biodistribution of $\mathrm{HA}-\mathrm{Bi}_{2} \mathrm{O}_{3} \mathrm{NPs}$ in vivo, the $\mathrm{HA}-\mathrm{Bi}_{2} \mathrm{O}_{3} \mathrm{NPs}$ solution $(40 \mathrm{mg} / \mathrm{kg}$ ) in PBS was injected into ICR mice via the tail vein. After $24 \mathrm{~h}$ postadministration, mice were sacrificed, and organs were dissected and weighed. For ICP-MS assay, each sample was added to $5 \mathrm{~mL}$ of $\mathrm{H}_{2} \mathrm{NO}_{3}$, transferred to flasks, and sealed for predigestion overnight. Then, $3 \mathrm{~mL}$ of $30 \% \mathrm{H}_{2} \mathrm{O}_{2}$ was added to each flask. The flasks were heated at $120^{\circ} \mathrm{C}$ for $2 \mathrm{~h}$ and then cooled to room temperature. A series of $\mathrm{Bi}^{+}$standard solutions $(0,0.5,1.5$, 10,50 , and $100 \mathrm{ppb}$ ) were prepared with the above solution. Both standard and test solutions were measured by ICP-MS. The amount of Bi elements was finally normalized to the cell number or tissue weight per gram.

\section{Live-dead staining assay and flow cytometry}

To study the radiosensitization effect of $\mathrm{HA}-\mathrm{Bi}_{2} \mathrm{O}_{3} \mathrm{NPs}$, SMMC-7721 cells were seeded in six-well plates at a density of $4.0 \times 10^{4}$ cells/well and allowed to grow for $12 \mathrm{~h}$ and divided into six groups (control, $\mathrm{HA}-\mathrm{Bi}_{2} \mathrm{O}_{3} \mathrm{NPs}$, radiation, radiation $+50 \mu \mathrm{g} / \mathrm{mL} \mathrm{HA}-\mathrm{Bi}_{2} \mathrm{O}_{3} \mathrm{NPs}$, radiation $+100 \mu \mathrm{g} / \mathrm{mL}$ $\mathrm{HA}-\mathrm{Bi}_{2} \mathrm{O}_{3} \mathrm{NPs}$, and radiation $+200 \mu \mathrm{g} / \mathrm{mL} \mathrm{HA}-\mathrm{Bi}_{2} \mathrm{O}_{3} \mathrm{NPs}$ ). When cells had grown to $80 \%$ in plates, the first group received no treatment, the second one was incubated with $200 \mu \mathrm{g} / \mathrm{mL} \mathrm{HA}-\mathrm{Bi}_{2} \mathrm{O}_{3} \mathrm{NPs}$ for $24 \mathrm{~h}$, the third one was just irradiated at $6 \mathrm{~Gy}$, and the fourth to sixth ones were irradiated at $6 \mathrm{~Gy}$, and at the same time, incubated with different concentrations of $\mathrm{HA}-\mathrm{Bi}_{2} \mathrm{O}_{3} \mathrm{NPs}(50,100$, and $200 \mu \mathrm{g} / \mathrm{mL})$ for $24 \mathrm{~h}$, respectively. After that, FDA and PI working buffer was added for cell staining. The fluorescence of stained cells was observed under a fluorescence microscope; live cells showed green color, and dead ones exhibited red color.

Furthermore, cells treated by different treatments were washed three times with PBS, digested, collected, and centrifuged at a speed of 2,000 rpm for $5 \mathrm{~min}$, and then fixed with $70 \%$ ethanol at $-20^{\circ} \mathrm{C}$ overnight followed by PI staining. DNA fragmentation was quantified by the fluorescence intensity of PI on a Beckman Coulter Epics XL MCL flow cytometer (BD Accuri C6) and analyzed by software (Flowjo 7.6.2) to clearly understand the cell cycle distribution and apoptosis.

\section{Clonogenic survival assays}

Cells were seeded in six-well plates at a density of $1.0 \times 10^{3}$ cells/ well and permitted to grow for $16 \mathrm{~h}$. The cells were incubated with $200 \mu \mathrm{g} / \mathrm{mL}$ HA-Bi ${ }_{2} \mathrm{O}_{3}$ NPs diluted in cell culture medium for $6 \mathrm{~h}$. The cells were then irradiated at $6 \mathrm{~Gy}$. After irradiation, cells were allowed to grow for 14 days, fixed with $4 \%$ paraformaldehyde at room temperature for $40 \mathrm{~min}$, and stained with $1 \%$ crystal violet after washing the cells. Cells were treated on a clinical linear accelerator (Oncor, Dallas, TX, USA) with $6 \mathrm{MV}$ irradiation under a radiation field of $10 \times 10 \mathrm{~cm}$ at a source-toskin distance (SSD) of $100 \mathrm{~cm}$ to cover the entire cells.

\section{In vivo and in vitro $C T$ imaging study and biodistribution of $\mathrm{HA}-\mathrm{Bi}_{2} \mathrm{O}_{3} \mathrm{NPs}$}

In vitro and in vivo CT images were acquired on a clinical 64-slice multidetector CT scanner (SOMATOM Emotion; Siemens, Munich, Germany). To study the CT images in vitro, the solutions of $\mathrm{HA}-\mathrm{Bi}_{2} \mathrm{O}_{3} \mathrm{NPs}$ with different concentrations ranging from 0 to $10 \mathrm{mg} / \mathrm{mL}$ were added to a 96 -well culture plate, using the commercial contrast Omnipaque (GE Healthcare (Shanghai) Co., Ltd., Shanghai, People's Republic of China) as control. The X-ray attenuation intensity was evaluated with the average values of gray density by the corresponding software (ImageJ) and medical image analysis system. For CT imaging in vivo, we choose the normal ICR mice as model. 
Animal experiments were performed strictly following the Animal Management Rules of the Ministry of Health of the People's Republic of China. HA-Bi ${ }_{2} \mathrm{O}_{3} \mathrm{NPs}(40 \mathrm{mg} / \mathrm{kg})$ filtered through sterilized membrane filters (pore size $0.22 \mu \mathrm{m}$ ) were intravenously injected into the animals before investigating with a CT scanner. These samples for CT imaging in vitro and animals in vivo were imaged with the following parameters: tube voltage, $130 \mathrm{kV}$; current intensity, $180 \mathrm{~mA}$; slice thickness, $5.0 \mathrm{~mm}$; and scan time, $2.85 \mathrm{~s}$. The corresponding dissected organs were treated with microwave digestion.

\section{Therapeutic evaluation of $\mathrm{HA}-\mathrm{Bi}_{2} \mathrm{O}_{3} \mathrm{NPs}$ in tumor-bearing mice}

Female ICR mice with body weights of 19-21 g and aged 6 weeks were obtained from Jiangsu University Laboratory Animal Center (No 201602201) and placed under the standard conditions $\left(20^{\circ} \mathrm{C} \pm 2{ }^{\circ} \mathrm{C}\right.$ room temperature, $60 \% \pm 10 \%$ relative humidity). Animals were acclimatized to this environment for 5 days prior to treatment. Animal experiments were consistent with the Animal Management Rules of the Ministry of Health of the People's Republic of China (SCXK(s) 2013-0011).

The technology of establishing the animal models with Herps cells is very mature. ${ }^{40}$ Animal models were established by the following procedures: First, $1 \times 10^{6}$ Herps cells were inoculated into mice intraperitoneally, and the ascites were collected after 5 days. Then, these ascites were injected subcutaneously at an SSD of $100 \mathrm{~cm}$. When the tumor sizes reached $\sim 100 \mathrm{~mm}^{3}$, subcutaneous tumors models were established and applied to the following experiments. To establish in situ tumor model, the tumor-bearing mice were sacrificed, and subcutaneously, tumors were dissected out. These solid tumors were cut into small pieces and inoculated into normal mice liver in situ. Five days post-inoculation, in situ tumor models were established.

Mice bearing subcutaneous tumors were treated with radiation at 3 Gy per fraction at a total dose of 30 Gy within 10 days. The radiotherapy was conducted after $3 \mathrm{~h}$ of intravenous injection of $\mathrm{HA}-\mathrm{Bi}_{2} \mathrm{O}_{3} \mathrm{NPs}(10 \mathrm{mg} / \mathrm{kg})$, on a Siemens Primus clinical linear accelerator $(6 \mathrm{MeV})$ using a radiation field of $10 \times 10 \mathrm{~cm}$ to cover the entire tumor. Tumor growth and mouse weight were measured in the following days. The tumor sizes were measured by a caliper and calculated as follows: $V=a b^{2} / 2$, where $V\left(\mathrm{~mm}^{3}\right)$ is the volume of the tumor, and $a(\mathrm{~mm})$ and $b(\mathrm{~mm})$ are the tumor length and tumor width, respectively. Relative tumor volumes were normalized to their initial sizes. Each group contained eight mice and statistical analysis was performed using Student's two-tailed $t$-test $(P<0.05, P<0.001)$.

\section{Results and discussion}

\section{Preparation and characterization of $\mathrm{HA}-\mathrm{Bi}_{2} \mathrm{O}_{3} \mathrm{NPs}$}

The HA- $\mathrm{Bi}_{2} \mathrm{O}_{3}$ NPs were successfully fabricated according to the illustrated diagram in Figure 1. In this study, the morphological examination was carried out by TEM, and the resultant particle sizes were analyzed by NanoDLS particle size analyzer. As shown in Figure 2A and B, TEM/HRTEM

A

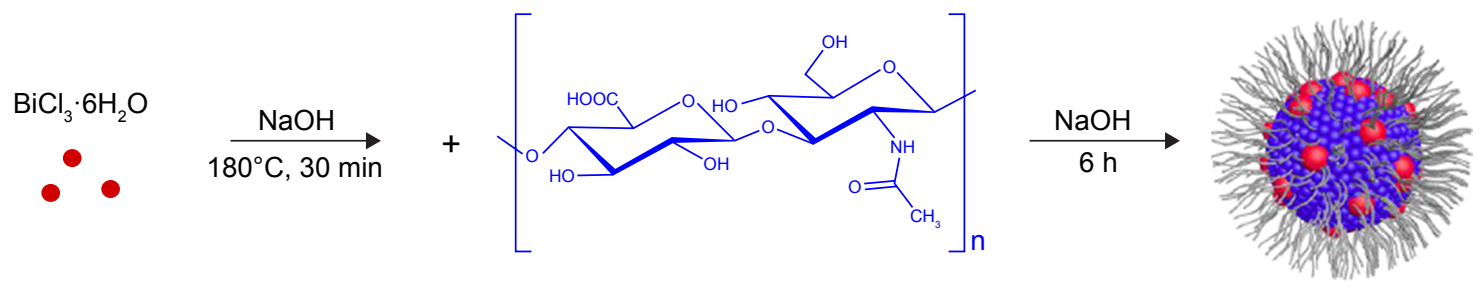

B Noninvasive imaging

Tumor targeting

Radiation enhancement

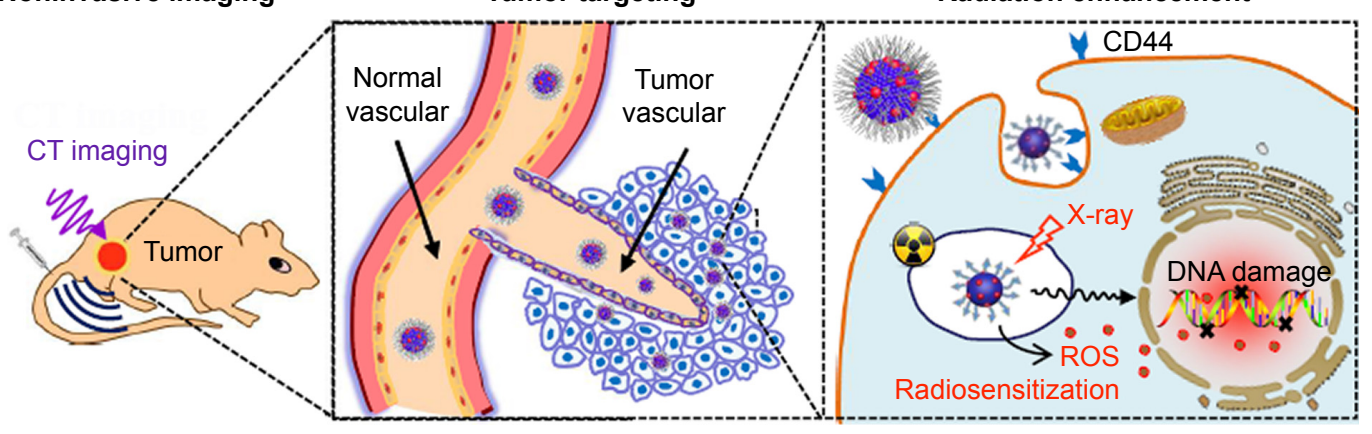

Figure I (A) Schematic synthesis of $\mathrm{HA}-\mathrm{Bi}_{2} \mathrm{O}_{3} \mathrm{NPs}$ by pyrolysis method and (B) the following biomedical applications.

Abbreviations: $\mathrm{HA}_{-}-\mathrm{Bi}_{2} \mathrm{O}_{3} \mathrm{NPs}$, hyaluronic acid-functionalized bismuth oxide nanoparticles; $\mathrm{ROS}$, reactive oxygen species; $\mathrm{CT}$, computed tomography. 
A
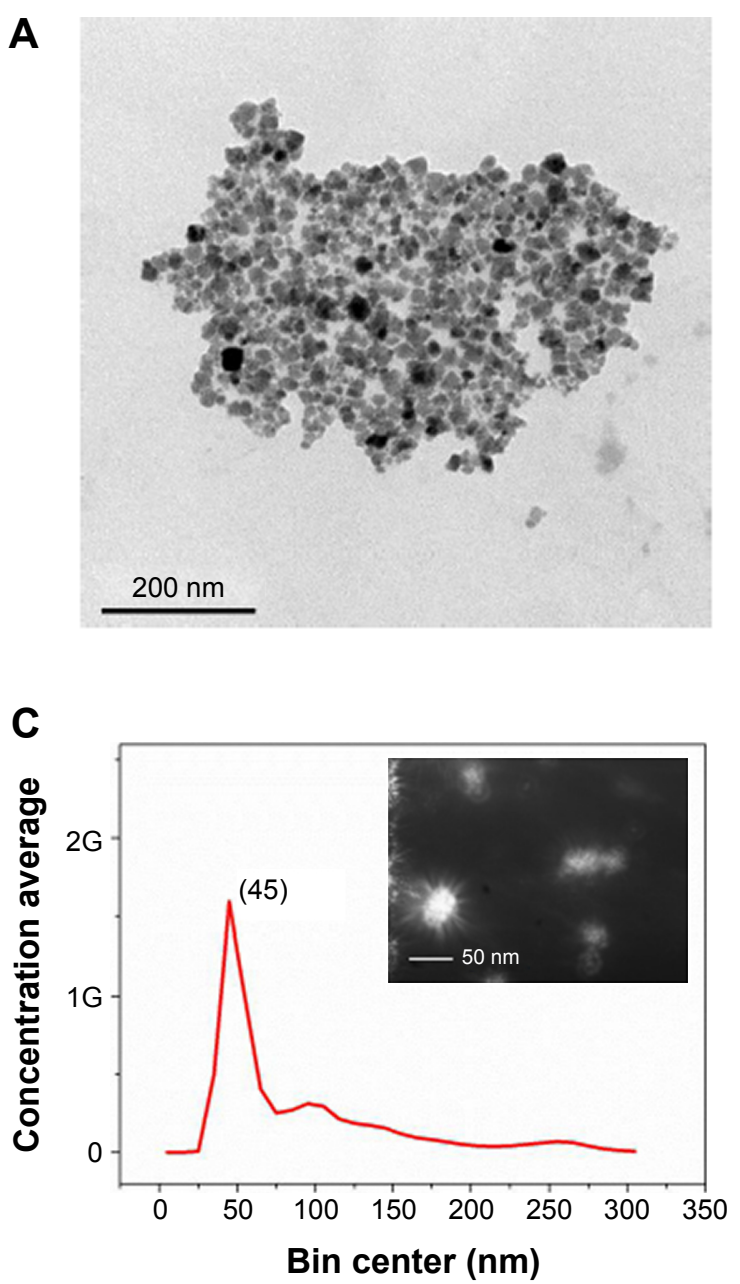

B

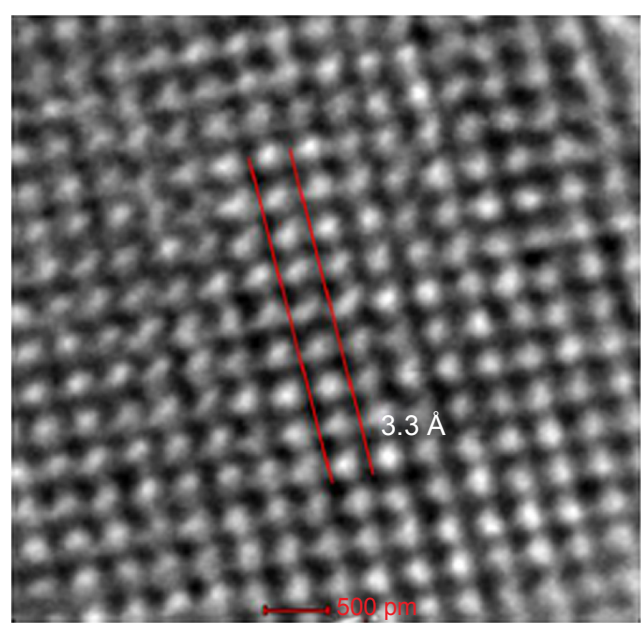

D

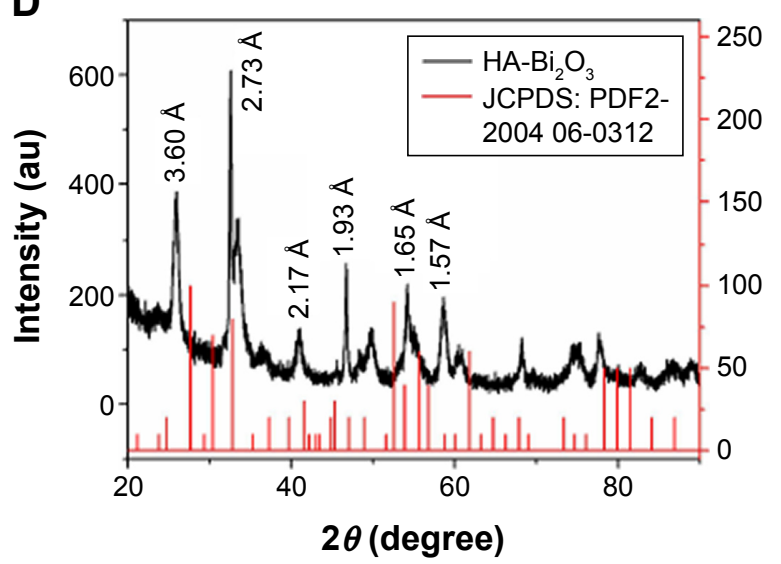

Figure 2 (A) TEM image of $\mathrm{HA}-\mathrm{Bi}_{2} \mathrm{O}_{3} \mathrm{NPs}$. (B) HRTEM image of $\mathrm{HA}-\mathrm{Bi}_{2} \mathrm{O}_{3} \mathrm{NPs}$. (C) Size distribution of $\mathrm{HA}-\mathrm{Bi}_{2} \mathrm{O}_{3} \mathrm{NPs}$. The inset shows the optical image of the HA-Bi $\mathrm{O}_{3} \mathrm{NPs}$. (D) XRD pattern of the $\mathrm{HA}-\mathrm{Bi}_{2} \mathrm{O}_{3} \mathrm{NPs}$.

Abbreviations: TEM, transmission electron microscopy; $\mathrm{HA}-\mathrm{Bi}_{2} \mathrm{O}_{3} \mathrm{NPs}$, hyaluronic acid-functionalized bismuth oxide nanoparticles; HRTEM, high-resolution transmission electron microscopy; XRD, X-ray diffraction; JCPDS: PDF, Joint Committee on Powder Diffraction Standards: powder diffraction file.

showed that the $\mathrm{HA}-\mathrm{Bi}_{2} \mathrm{O}_{3}$ NPs all exhibited uniform dispersion and discrete quasi-spherical shape without apparent aggregation. $\mathrm{HA}-\mathrm{Bi}_{2} \mathrm{O}_{3} \mathrm{NPs}$ had a diameter of $45 \pm 0.6 \mathrm{~nm}$ and possessed a uniform lattice structure with a lattice fringe of interlayer spacing $(d)=3.3 \pm 0.2 \AA$. Dynamic light scattering measurement showed that $\mathrm{HA}-\mathrm{Bi}_{2} \mathrm{O}_{3} \mathrm{NPs}$ had uniform size distribution (Figure 2C). As shown in Figure S1, the average diameter of $\mathrm{HA}-\mathrm{Bi}_{2} \mathrm{O}_{3}$ NPs in aqueous solution was maintained stable with an average size of $50 \mathrm{~nm}$ for 8 days. The average size of HA- $\mathrm{Bi}_{2} \mathrm{O}_{3}$ NPs in PBS solution remained at $47.4 \mathrm{~nm}$ on the first day. The average diameters of $\mathrm{HA}-\mathrm{Bi}_{2} \mathrm{O}_{3} \mathrm{NPs}$ were slightly influenced and ranged from 47.4 to $53.7 \mathrm{~nm}$ for 8 days. Compared to normal tissues, capillary endothelial permeability of tumor tissues was increased, and the endothelial gap was between 100 and $600 \mathrm{~nm} .{ }^{41}$ Therefore, NPs with desirable size are beneficial to accumulate in the tumor tissues and dramatically improve the passive targeting drug delivery efficiency.

\section{Chemical structure and surface} composition of the $\mathrm{HA}-\mathrm{Bi}_{2} \mathrm{O}_{3} \mathrm{NPs}$

Surface functional groups and composition of the HA$\mathrm{Bi}_{2} \mathrm{O}_{3}$ NPs were investigated using FT-IR spectrum and XPS pattern. FT-IR spectrum was obtained for both naked $\mathrm{Bi}_{2} \mathrm{O}_{3}$ and $\mathrm{HA}-\mathrm{Bi}_{2} \mathrm{O}_{3}$ NPs (Figure S2). For the HA- $\mathrm{Bi}_{2} \mathrm{O}_{3}$ NPs, the characteristic absorption bands of $v_{\text {as }} \mathrm{O}-\mathrm{C}-\mathrm{O}$ at $1,380 \mathrm{~cm}^{-1}$ demonstrated the presence of carbonate groups. The broad peaks at 3,340 and $2,900 \mathrm{~cm}^{-1}$ were attributed to the $\mathrm{O}-\mathrm{H}$ and $\mathrm{C}-\mathrm{H}$ stretching vibrations, respectively, which corresponded to the surface-adsorbed water. The stretching vibrations of $v_{\text {as }} \mathrm{O}-\mathrm{C}-\mathrm{O}$ were enhanced, indicating the introduction of carboxylic group of HA. These results showed that the functional groups of $\mathrm{HA}-\mathrm{Bi}_{2} \mathrm{O}_{3} \mathrm{NPs}$ mainly contained certain plentiful $\mathrm{C}=\mathrm{O},-\mathrm{COOH}$, and $-\mathrm{OH}$ groups. The presence of these functional groups located at their surface endowed the $\mathrm{HA}-\mathrm{Bi}_{2} \mathrm{O}_{3}$ NPs with excellent 

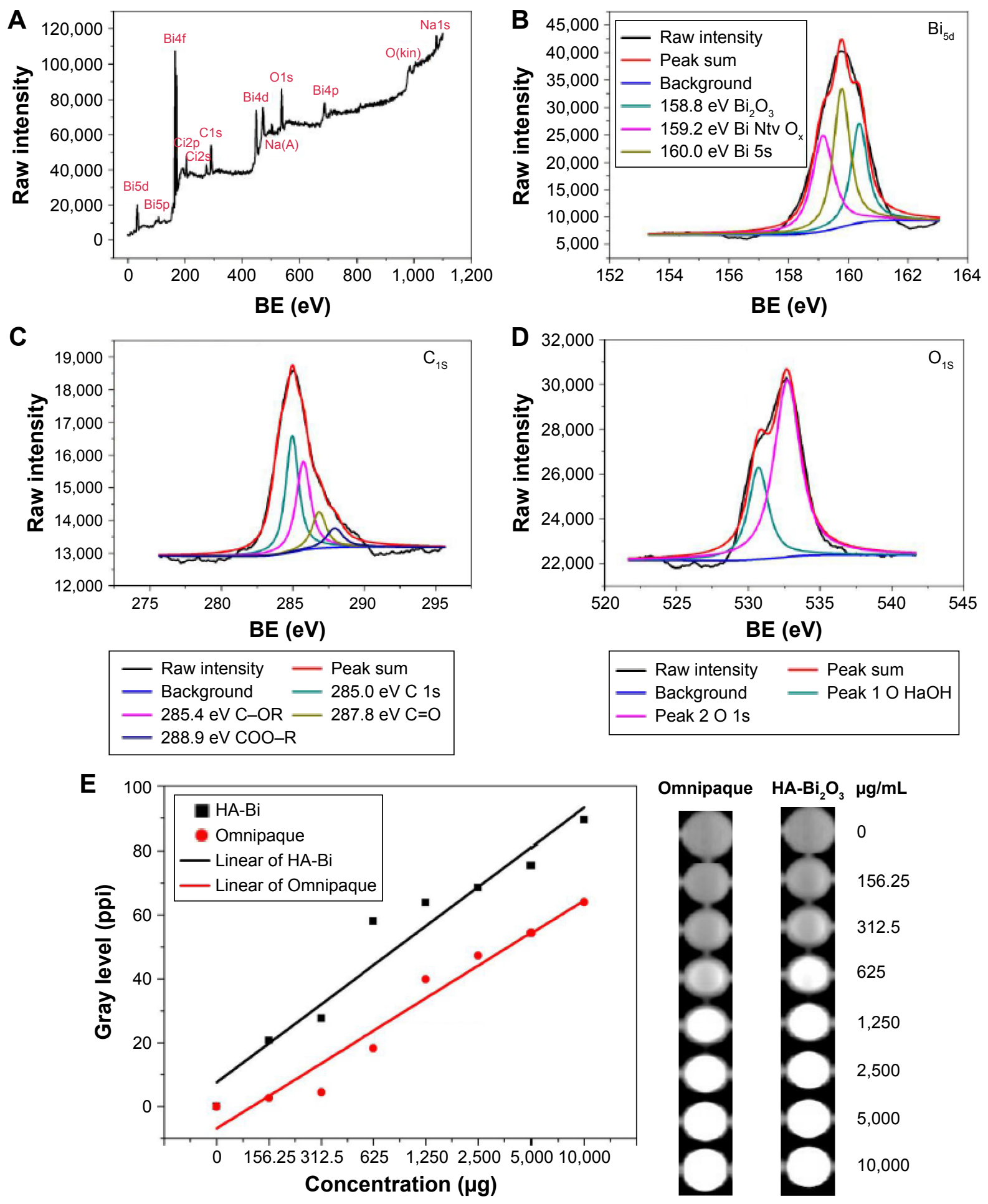

Figure 3 XPS spectra of the $\mathrm{HA}_{-} \mathrm{Bi}_{2} \mathrm{O}_{3}$ NPs. (A) Survey spectrum. (B) $\mathrm{Bi}_{5 d}$ spectrum. (C) $\mathrm{C}_{1 \mathrm{~S}}$ spectrum. (D) $\mathrm{O}_{1 \mathrm{~s}}$ spectrum. (E) CT images in PBS with different concentrations of $\mathrm{HA}-\mathrm{Bi}_{2} \mathrm{O}_{3} \mathrm{NPs}$ and Omnipaque solution. Fitting curve of gray level.

Note: Is, 2p, 2s, 4d, 4p, 4f, 5d, and $5 p$ are azimuthal quantum numbers.

Abbreviations: XPS, X-ray photoelectron spectroscopy; $\mathrm{HA}-\mathrm{Bi}_{2} \mathrm{O}_{3} \mathrm{NPs}$, hyaluronic acid-functionalized bismuth oxide nanoparticles; CT, computed tomography; $\mathrm{BE}$, binding energy; PBS, phosphate-buffered saline; $\mathrm{Bi}$, bismuth; Adj $R^{2}$, adjusted coefficient of determination.

hydrophilicity and dispersibility in water. ${ }^{42}$ The survey XPS spectrum (Figure 3A) showed three typical peaks at 159.75, 285.1, and $532.65 \mathrm{eV}$, which indicated that the $\mathrm{HA}-\mathrm{Bi}_{2} \mathrm{O}_{3}$ NPs were mainly composed of bismuth, carbon, and oxygen elements. The high-resolution spectrum of $\mathrm{Bi}_{5 \mathrm{~d}}$ (Figure $3 \mathrm{~B}$ ) revealed the presence of three strong peaks at 158.8, 159.2, and $160.0 \mathrm{eV}$ with a spin-orbit splitting of $32 \mathrm{eV}$ corresponding, respectively, to the $\mathrm{Bi}_{2} \mathrm{O}_{3}$, native oxide ( $\mathrm{Ntv} \mathrm{Ox}$ ), and 
1s energy levels of $\mathrm{Bi}$. These observations were in good agreement with previous reports for $\mathrm{Bi}_{2} \mathrm{O}_{3} \mathrm{NPs}^{43}$ The $\mathrm{C}$ (1s) spectrum as shown in Figure 3C was dominated by four major peaks positioned at 285.0, 285.4, 287.8, and $531.8 \mathrm{eV}$, which corresponded, respectively, to the $1 \mathrm{~s}, \mathrm{C}-\mathrm{OR}, \mathrm{C}=\mathrm{O}$, and COO-R energy levels of $\mathrm{C}$ atom. The $\mathrm{O}(1 \mathrm{~s})$ spectrum as shown in Figure 3D was dominated by two major peaks positioned at 530.5 and $531.8 \mathrm{eV}$, which corresponded to the bond between $\mathrm{O}(\mathrm{NaOH})$ and $\mathrm{O}(1 \mathrm{~s})$.

The crystal structure of the $\mathrm{HA}-\mathrm{Bi}_{2} \mathrm{O}_{3} \mathrm{NPs}$ was investigated by $\mathrm{X}$-ray diffraction. As shown in Figure 2D, there were diffraction peaks in the $\mathrm{HA}-\mathrm{Bi}_{2} \mathrm{O}_{3} \mathrm{NP}$ pattern around $24.710^{\circ}$ $(d=0.360 \mathrm{~nm}$, grade of tolerance $[\mathrm{hkl}]=220$ plane $), 32.778^{\circ}$ $(d=0.273 \mathrm{~nm}, \mathrm{hkl}=321$ plane $), 41.583^{\circ}(d=0.217 \mathrm{~nm}, \mathrm{hkl}=332$ plane $), 47.045^{\circ}(d=0.193 \mathrm{~nm}, \mathrm{hkl}=311$ plane $), 55.658^{\circ}$ $(d=0.165 \mathrm{~nm}, \mathrm{hkl}=610$ plane $), 58.763^{\circ}(d=0.157 \mathrm{~nm}$, $\mathrm{hkl}=621$ plane), and other crystal planes, which corresponded to the characteristic peaks of $\alpha-\mathrm{Bi}_{2} \mathrm{O}_{3}$ (monoclinic system), respectively. The corresponding $d$ was calculated according to the Bragg's law (the wavelength of $\mathrm{Cu}-\mathrm{K} \alpha$ is $0.154 \mathrm{~nm}$ ). These diffraction peaks matched well with the characteristic peaks of cubic $\mathrm{Bi}_{2} \mathrm{O}_{3}$ (JCPDS 2004 06-0312).

\section{$X$-ray attenuation capacity of the $\mathrm{HA}-\mathrm{Bi}_{2} \mathrm{O}_{3} \mathrm{NPs}$}

We then investigated the X-ray attenuation capacity of the $\mathrm{HA}-\mathrm{Bi}_{2} \mathrm{O}_{3}$ NPs compared with the Omnipaque (commercial CT CAs). As shown in Figure 3E, the CT image brightness increased with the $\mathrm{HA}-\mathrm{Bi}_{2} \mathrm{O}_{3}$ NPs concentration, which was similar to the behavior of the Omnipaque solution. At the $\mathrm{HA}-\mathrm{Bi}_{2} \mathrm{O}_{3} \mathrm{NP}$ concentration of 156.25 to $1 \times 10^{4} \mu \mathrm{g} / \mathrm{mL}$, the mean gray values were $137.3(156.25 \mu \mathrm{g} / \mathrm{mL}), 167.6$ (312.5 $\mu \mathrm{g} / \mathrm{mL}), 173.5(625 \mu \mathrm{g} / \mathrm{mL}), 178.1\left(1.25 \times 10^{4} \mu \mathrm{g} / \mathrm{mL}\right)$, $185.1\left(2.5 \times 10^{3} \mu \mathrm{g} / \mathrm{mL}\right)$, and $199.1\left(1 \times 10^{4} \mu \mathrm{g} / \mathrm{mL}\right)$; at the Omnipaque concentration of 156.25 to $1 \times 10^{4} \mu \mathrm{g} / \mathrm{mL}$, the mean gray values were $114.1(156.25 \mu \mathrm{g} / \mathrm{mL}), 127.9$ (312.5 $\mu \mathrm{g} / \mathrm{mL}), 149.5(625 \mu \mathrm{g} / \mathrm{mL}), 156.9\left(1.25 \times 10^{4} \mu \mathrm{g} / \mathrm{mL}\right)$, $164.0\left(2.5 \times 10^{3} \mu \mathrm{g} / \mathrm{mL}\right)$, and $173.7\left(1 \times 10^{4} \mu \mathrm{g} / \mathrm{mL}\right)$. The CT image of $\mathrm{HA}-\mathrm{Bi}_{2} \mathrm{O}_{3} \mathrm{NPs}$ was much brighter than that of Omnipaque under the same dosage of radiation. Further quantitative analysis data showed that $\mathrm{X}$-ray attenuation intensity of both $\mathrm{HA}-\mathrm{Bi}_{2} \mathrm{O}_{3}$ NPs and the Omnipaque increased with the mass concentration of radiodense element. Nevertheless, the $\mathrm{HA}-\mathrm{Bi}_{2} \mathrm{O}_{3}$ NPs exhibited much higher X-ray attenuation capacity than Omnipaque under the same radioactive element concentrations ( $\geq 156.25 \mu \mathrm{g} / \mathrm{mL})$. The superior X-ray attenuation performance endowed $\mathrm{HA}-\mathrm{Bi}_{2} \mathrm{O}_{3}$ with ideal CT imaging capacity for identifying accurate localization of tumor tissue.

\section{Cellular binding and phagocytosis tests}

The $\mathrm{HA}-\mathrm{Bi}_{2} \mathrm{O}_{3}$ NPs uptaken by cells were quantitatively evaluated using flow cytometry method. Cells were incubated with $100 \mu \mathrm{g} / \mathrm{mL}$ of the $\mathrm{HA}-\mathrm{Bi}_{2} \mathrm{O}_{3} \mathrm{NPs}$ for $6 \mathrm{~h}$. Ten thousand cells were collected and analyzed by flow cytometry (Figure 4A and B). The single-color histograms indicated that the number of cells labeled by FITC-modified HA$\mathrm{Bi}_{2} \mathrm{O}_{3}$ NPs was 97.66\% (SMMC-7721) and 86.64\% (MCF7), respectively. The results validated that $\mathrm{HA}-\mathrm{Bi}_{2} \mathrm{O}_{3} \mathrm{NPs}$ were readily internalized by cancer cells.

In order to verify the HA receptor-mediated cellular uptake behavior, SMMC-7721 (CD44 high-expression cell line) and MCF7 cells (CD44 low-expression cell line) were pretreated with free $\mathrm{HA}$ before incubation with $\mathrm{HA}-\mathrm{Bi}_{2} \mathrm{O}_{3}$ NPs. As previously reported, ${ }^{44}$ relative expression of CD44 in SMMC-7721 was higher than in MCF7 according to realtime PCR results; relative expression of CD44 in MCF7 was only $25.6 \%$ of the expression in SMMC-7721 (Figure S3). From flow cytometry assay, it was found that the amount of $\mathrm{HA}-\mathrm{Bi}_{2} \mathrm{O}_{3}$ uptaken by SMMC-7721 cells (93.94\%) was more than that of MCF7 cells (85.90\%) (Figure 4C and D). As expected, the uptake of $\mathrm{HA}-\mathrm{Bi}_{2} \mathrm{O}_{3} \mathrm{NPs}$ was reduced to $68.19 \%$ in SMMC-7721 cells, but a slight change $(75.88 \%)$ in MCF7 cells was observed when the two cell lines were pretreated simultaneously with free HA. Free HA was able to bind to $\mathrm{CD} 44$ and inhibited the binding of $\mathrm{HA}-\mathrm{Bi}_{2} \mathrm{O}_{3}$ to CD44 competitively; the influence of free HA on SMMC7721 was noticeable because relative expression of CD44 in SMMC-7721 cells was higher than in MCF7 cells. These results suggest that $\mathrm{HA}-\mathrm{Bi}_{2} \mathrm{O}_{3} \mathrm{NPs}$ could be effectively taken up through the HA receptor-mediated endocytosis. It was also worthy of note that SMMC-7721 cells exhibited much higher uptake of $\mathrm{HA}-\mathrm{Bi}_{2} \mathrm{O}_{3}$ NPs than MCF7 cells, implying the synergistic effect of CD44 on cellular internalization of $\mathrm{HA}-\mathrm{Bi}_{2} \mathrm{O}_{3}$ NPs.

In addition, we further employed confocal laser scanning microscopy to observe the intracellular distribution of FITClabeled HA- $\mathrm{Bi}_{2} \mathrm{O}_{3}$ NPs in SMMC-7721 and MCF7 cells stained with LysoTracker Red DND-26 probe. Figure 4E shows that $\mathrm{HA}-\mathrm{Bi}_{2} \mathrm{O}_{3}$ NPs with green fluorescence exhibited a colocalization in the lysosomes with red fluorescence. Based on the data, we could speculate that $\mathrm{HA}-\mathrm{Bi}_{2} \mathrm{O}_{3}$ NPs may be preferably internalized into the lysosomes after receptor-mediated endocytosis. More importantly, the green fluorescence was more noticeable in SMMC-7721 than in MCF7. Because free 
A

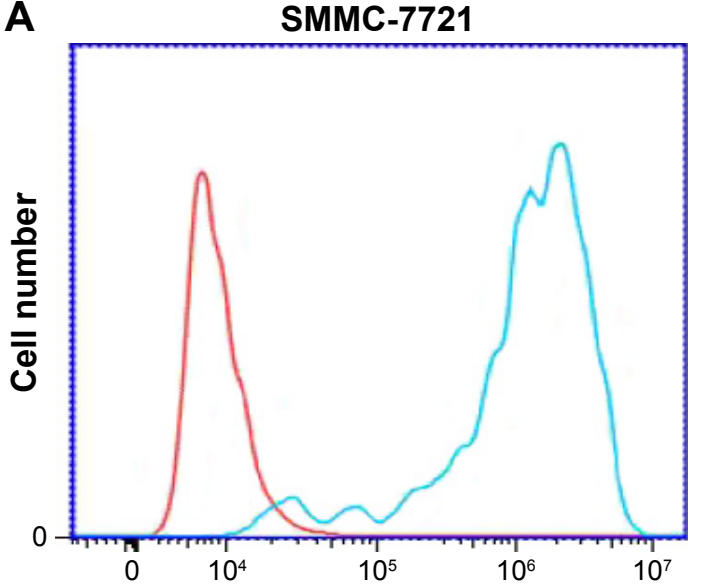

Fluorescence intensity
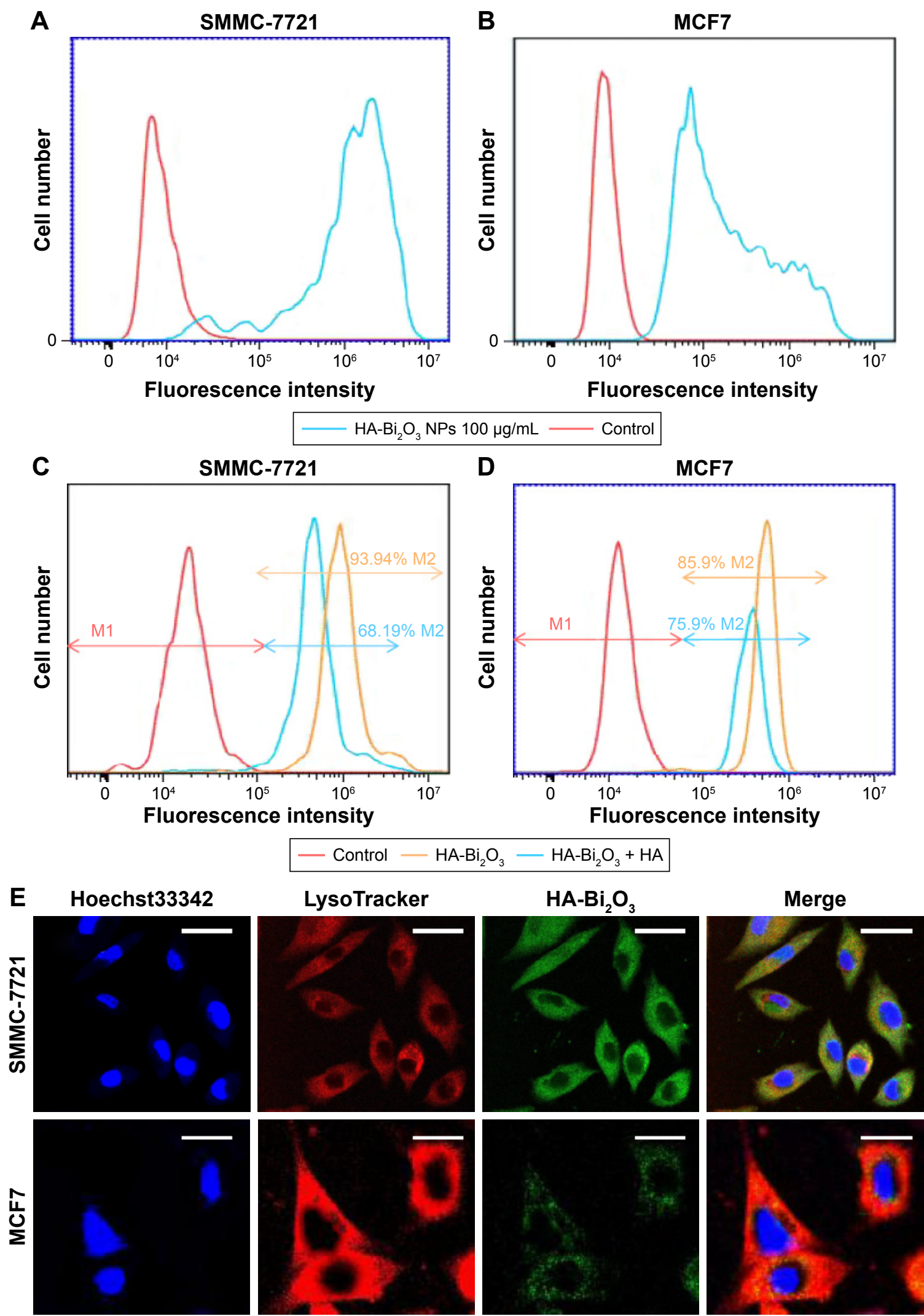

Figure 4 (A and B) Fluorescence signal intensity of SMMC-772I and MCF7 cells incubated with FITC-HA-Bi $\mathrm{O}_{3}$ NPs (through FLI). (C and D) The effect of free HA on the fluorescence signal intensity of SMMC-772I and MCF7 cells after incubation with FITC-labeled $\mathrm{HA}_{-} \mathrm{Bi}_{2} \mathrm{O}_{3} \mathrm{NPs}$. (E) Fluorescence images of SMMC-772I (scale bars $=20 \mu \mathrm{m}$ ) and MCF7 (scale bars $=10 \mu \mathrm{m}$ ) cells after exposure to $\mathrm{HA}-\mathrm{Bi}_{2} \mathrm{O}_{3} \mathrm{NPs}$. Cells were stained with Hoechst33342 and LysoTracker. HA-Bi ${ }_{2} \mathrm{O}_{3} \mathrm{NPs}$ were modified with FITC. Abbreviations: FITC, fluorescein isothiocyanate; FITC-HA- $\mathrm{Bi}_{2} \mathrm{O}_{3} \mathrm{NPs}$, FITC-labeled $\mathrm{HA}-\mathrm{Bi}_{2} \mathrm{O}_{3} \mathrm{NPs} ; \mathrm{HA}$, hyaluronic acid; $\mathrm{HA}-\mathrm{Bi}_{2} \mathrm{O}_{3} \mathrm{NPs}$, $\mathrm{HA}$-functionalized bismuth oxide nanoparticles. 
HA can compete with CD44 binding, $\mathrm{HA}-\mathrm{Bi}_{2} \mathrm{O}_{3}$ NPs were more easily internalized by SMMC-7721 cells than MCF7 cells, implying the synergistic effect of CD44 on cellular internalization of $\mathrm{HA}-\mathrm{Bi}_{2} \mathrm{O}_{3}$ NPs.

\section{Cytotoxicity and intracellular tracking of the $\mathrm{HA}-\mathrm{Bi}_{2} \mathrm{O}_{3} \mathrm{NPs}$}

As potential biomedical agents, the $\mathrm{HA}-\mathrm{Bi}_{2} \mathrm{O}_{3}$ NPs are expected to possess good biocompatibility for their biomedical application. Firstly, the inherent cytotoxicity of HA- $\mathrm{Bi}_{2} \mathrm{O}_{3}$ NPs was assessed in MCF7, SMMC-7721, and VSMC cells via MTS assay. As shown in Figure 5A, all the $\mathrm{HA}-\mathrm{Bi}_{2} \mathrm{O}_{3}$ NPs at different concentrations exhibited negligible cytotoxicity. Even at the concentration of $400 \mu \mathrm{g} / \mathrm{mL}$ and with 24 -h exposure time, the cell viability was $\sim 90 \%$. Second, the hemocompatibility of the $\mathrm{HA}-\mathrm{Bi}_{2} \mathrm{O}_{3}$ NPs in vitro was estimated using hemolysis assay. As shown in Figures 5B and S4, we obviously found the hemolysis of red blood cells in the positive control. On the contrary, no obvious hemolysis phenomenon was observed after incubation with different concentrations from 12.5 to $400 \mu \mathrm{g} /$ $\mathrm{mL}$ for 2 hours administration, which was similar to the negative normal saline. Compared to the negative control, the percentage of hemolysis at different concentration of $\mathrm{HA}-\mathrm{Bi}_{2} \mathrm{O}_{3}$ NPs was quantitatively evaluated based on the absorbance the supernatant at $541 \mathrm{~nm}$. The results showed that the hemolysis percentages of the $\mathrm{HA}-\mathrm{Bi}_{2} \mathrm{O}_{3}$ NPs were all less than $7 \%$ in the studied concentration range from 25 to $800 \mu \mathrm{g} / \mathrm{mL}$, which verified their favorable hemocompatibility. These results clearly indicated that the assynthesized $\mathrm{HA}-\mathrm{Bi}_{2} \mathrm{O}_{3}$ NPs had very low cytotoxicity and good hemobiocompatibility.

\section{Biodistribution and histocompatibility of the $\mathrm{HA}-\mathrm{Bi}_{2} \mathrm{O}_{3} \mathrm{NPs}$ in vivo}

To further investigate whether $\mathrm{HA}-\mathrm{Bi}_{2} \mathrm{O}_{3} \mathrm{NPs}$ could induce adverse effects (such as tissue damage, inflammation, or lesions) in the long term postinjection, we carried out a
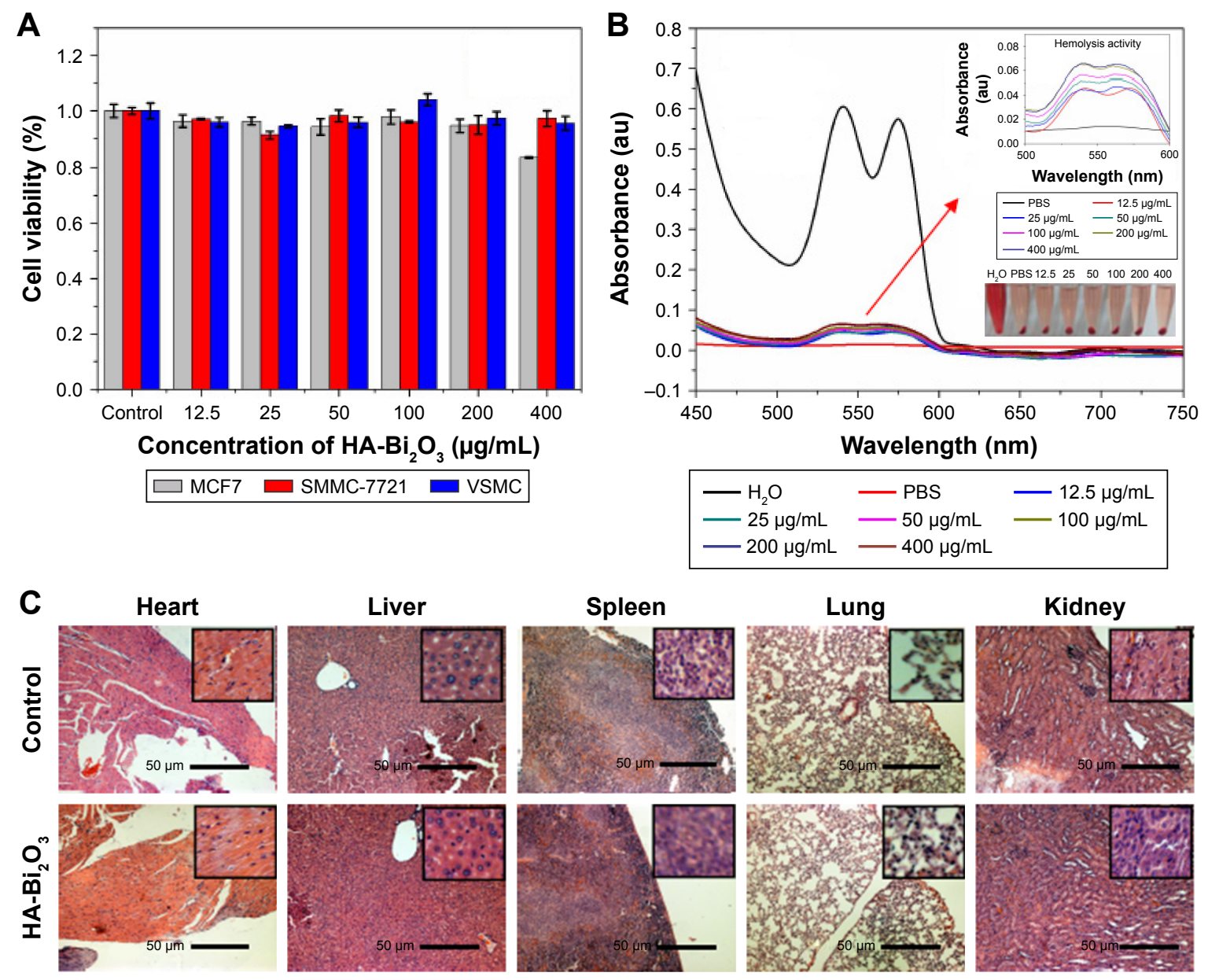

Figure 5 (A) The effect of $\mathrm{HA}-\mathrm{Bi}_{2} \mathrm{O}_{3} \mathrm{NPs}$ concentration on the viability of MCF7, SMMC-772I, and VSMC cells. (B) Hemolysis activity of the HA-Bi $\mathrm{O}_{3} \mathrm{NPs}$ at different concentrations. PBS and water treatment were used as negative and positive controls, respectively. Arrow represents fractionated gain. (C) The H\&E images of major organs after tail intravenous injections of $\mathrm{HA}_{-} \mathrm{Bi}_{2} \mathrm{O}_{3} \mathrm{NPs}$. Scale bars $=50 \mu \mathrm{m}$.

Abbreviations: $\mathrm{HA}-\mathrm{Bi}_{2} \mathrm{O}_{3} \mathrm{NPs}$, hyaluronic acid-functionalized bismuth oxide nanoparticles; PBS, phosphate-buffered saline. 
histological assessment of the susceptible organs of the mice (liver, heart, spleen, lung, and kidney) 30 days postadministration. As shown in Figure 5C, no obvious adverse effect associated with the administration of the $\mathrm{HA}-\mathrm{Bi}_{2} \mathrm{O}_{3}$ NPs was observed compared with the control group. The ICP-MS (Figure S5) results reported that the $\mathrm{HA}-\mathrm{Bi}_{2} \mathrm{O}_{3}$ NPs presented more appreciable accumulation in the liver $(27.80 \mu \mathrm{g} / \mathrm{g})$ than in the heart $(4.83 \mu \mathrm{g} / \mathrm{g})$, lung $(2.10 \mu \mathrm{g} / \mathrm{g})$, spleen $(6.17 \mu \mathrm{g} / \mathrm{g})$, and kidney $(7.40 \mu \mathrm{g} / \mathrm{g})$. However, the in vivo toxicity assessment profiles confirmed that the liver was unaffected by the accumulation of $\mathrm{HA}-\mathrm{Bi}_{2} \mathrm{O}_{3} \mathrm{NPs}$ at least in the long term. These preliminary results proved that HA$\mathrm{Bi}_{2} \mathrm{O}_{3}$ NPs at the given dose hardly caused in vivo toxicity effects in the long term post-administration.

\section{Tumor-targeted CT imaging}

The possibility of using $\mathrm{HA}-\mathrm{Bi}_{2} \mathrm{O}_{3} \mathrm{NPs}$ as CAs for CT imaging in vivo was studied using Cancer Research mice (ICR mice) as a model (Figure S6). After intravenous injection of $\mathrm{HA}-\mathrm{Bi}_{2} \mathrm{O}_{3}$ NPs at a dose of $20 \mathrm{mg} / \mathrm{kg}$, the CT images were acquired through different scan times. Figure $5 \mathrm{~A}$ and $\mathrm{B}$ shows that $\mathrm{HA}-\mathrm{Bi}_{2} \mathrm{O}_{3}$ NPs exhibited gradual increases of CT signal intensities in tumor within $10 \mathrm{~min}$. Compared with preinjection, a great contrast enhancement in tumor was observed clearly, indicating that $\mathrm{HA}-\mathrm{Bi}_{2} \mathrm{O}_{3} \mathrm{NPs}$ caused a time-dependent increase of signals and exhibited a strong $\mathrm{CT}$ imaging capability at 10 min postinjection. Figure $6 \mathrm{~A}$ and $\mathrm{B}$ also shows that the signal in both the kidney and bladder strongly increased at 30 min postinjection, which indicated the effective clearance of $\mathrm{HA}-\mathrm{Bi}_{2} \mathrm{O}_{3} \mathrm{NPs}$ from the body via renal metabolism. These results were further confirmed through CT transverse scans at different levels.

\section{Radiosensitization of $\mathrm{HA}-\mathrm{Bi}_{2} \mathrm{O}_{3} \mathrm{NPs}$ in vitro}

Previous studies have demonstrated that heavy metal-based radiosensitizers could absorb high-energy photons and emit secondary electrons and Auger electrons, which trigger a series of biological and chemical effects, such as destruction of DNA, proteins, and other intracellular components. ${ }^{47,48}$ The therapeutic effectiveness of radiotherapy could not be realized completely due to inaccurate localization and inherent radioresistance of tumors. To address these limits, the excellent performance of $\mathrm{HA}-\mathrm{Bi}_{2} \mathrm{O}_{3} \mathrm{NPs}$ as CAs in vitro has encouraged us to perform an in vivo experiment to investigate whether its potential could be applied to improve spatial localization accuracy for X-ray $\mathrm{CT}$ in radiosensitization of tumors. Firstly, cell counting kit-6 (cck8) assay was conducted to explore whether any dose enhancement was caused by this combination treatment. As depicted in Figure 7A, HA$\mathrm{Bi}_{2} \mathrm{O}_{3}$ NPs-only (concentration ranging from 0 to $400 \mu \mathrm{g} / \mathrm{mL}$ ) treatment had no significant influence on the SMMC-7721 cell viability, and X-ray (ranging from 0 to $9 \mathrm{~Gy}$ ) irradiation treatment decreased the SMMC-7721 cell viability to $45 \%$ at 9 Gy. Especially, the combination of X-ray irradiation with HA- $\mathrm{Bi}_{2} \mathrm{O}_{3}$ NPs dramatically decreased the SMMC-7721 cell viability to $<25 \%$ with the concentration of $200 \mu \mathrm{g} / \mathrm{mL}$ at $6 \mathrm{~Gy}$. Next, clonogenic assay in SMMC-7721 cells was conducted to evaluate the change in cell viability caused by the combination treatment of $\mathrm{X}$-ray irradiation and $\mathrm{HA}-\mathrm{Bi}_{2} \mathrm{O}_{3}$
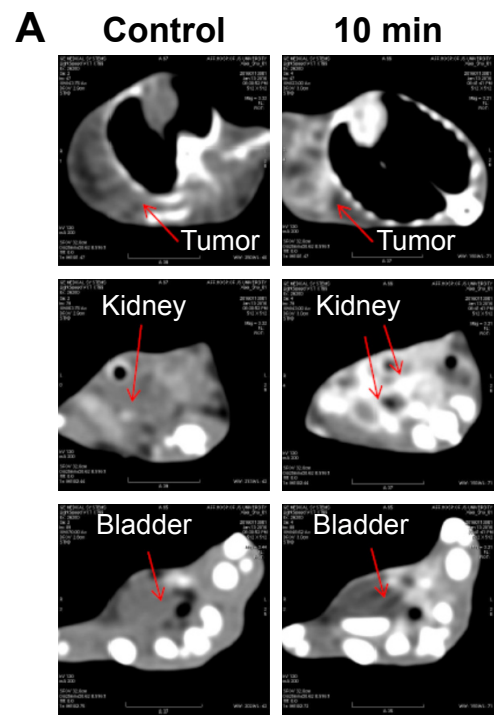
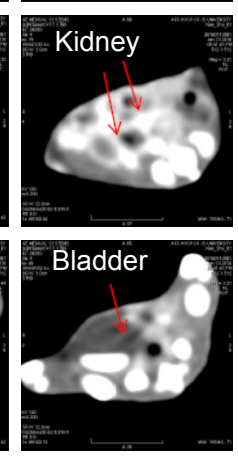

$30 \mathrm{~min}$
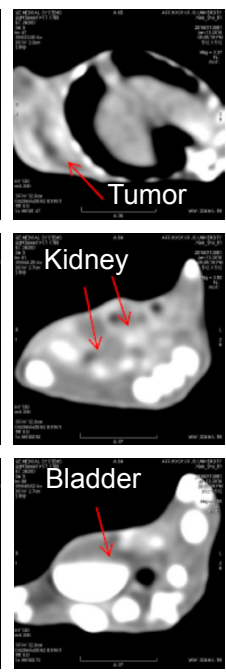

B

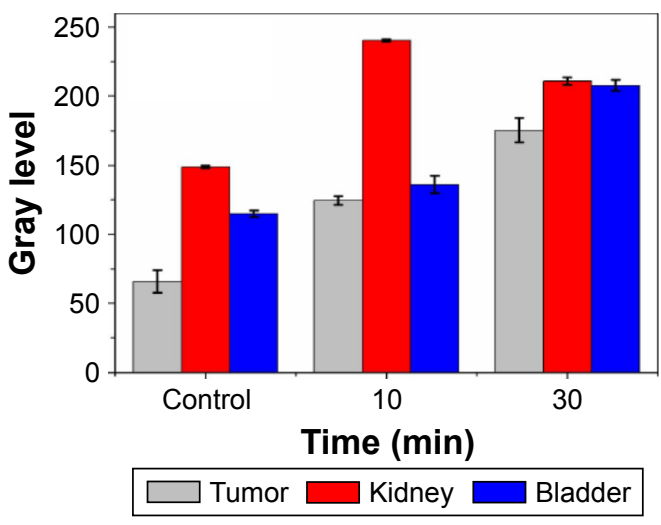

Figure 6 (A) Herps tumor-bearing mice at preinjection and $3 \mathrm{~h}$ after intravenous injection of $\mathrm{HA}_{-} \mathrm{Bi}_{2} \mathrm{O}_{3} \mathrm{NPs}$ (targeted group). Arrows represent the designated areas. (B) The corresponding CT value changes in the tumor and tissue distributions of NPs in vivo.

Abbreviations: $\mathrm{HA}-\mathrm{Bi}_{2} \mathrm{O}_{3} \mathrm{NPs}$, hyaluronic acid-functionalized bismuth oxide NPs; CT, computed tomography; NPs, nanoparticles. 
A

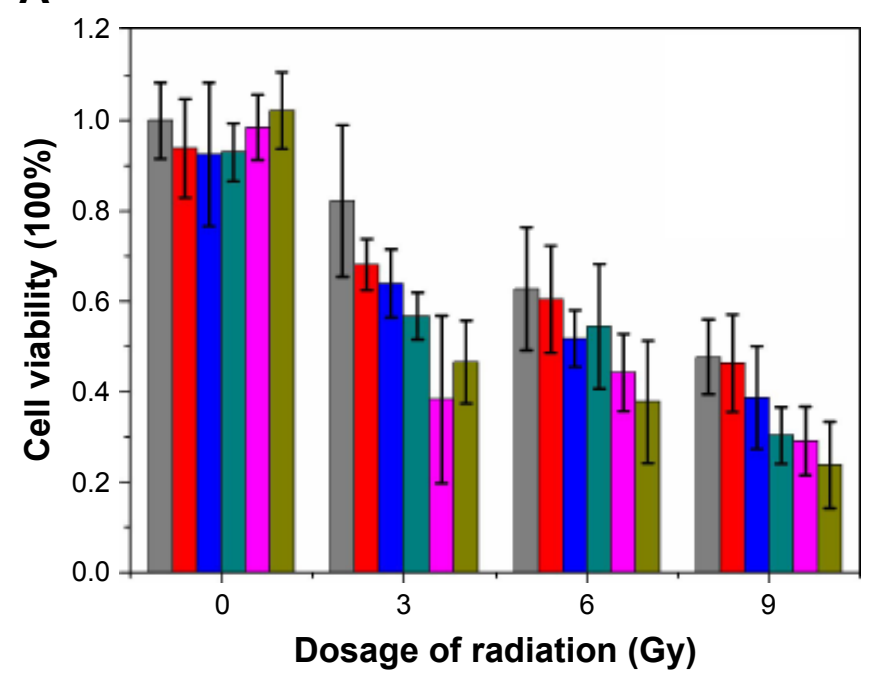

$\square 0 \mu \mathrm{g} / \mathrm{mL} \square 25 \mu \mathrm{g} / \mathrm{mL} \square 50 \mu \mathrm{g} / \mathrm{mL}$
$\square 100 \mu \mathrm{g} / \mathrm{mL} \square 200 \mu \mathrm{g} / \mathrm{mL} \square 400 \mu \mathrm{g} / \mathrm{mL}$
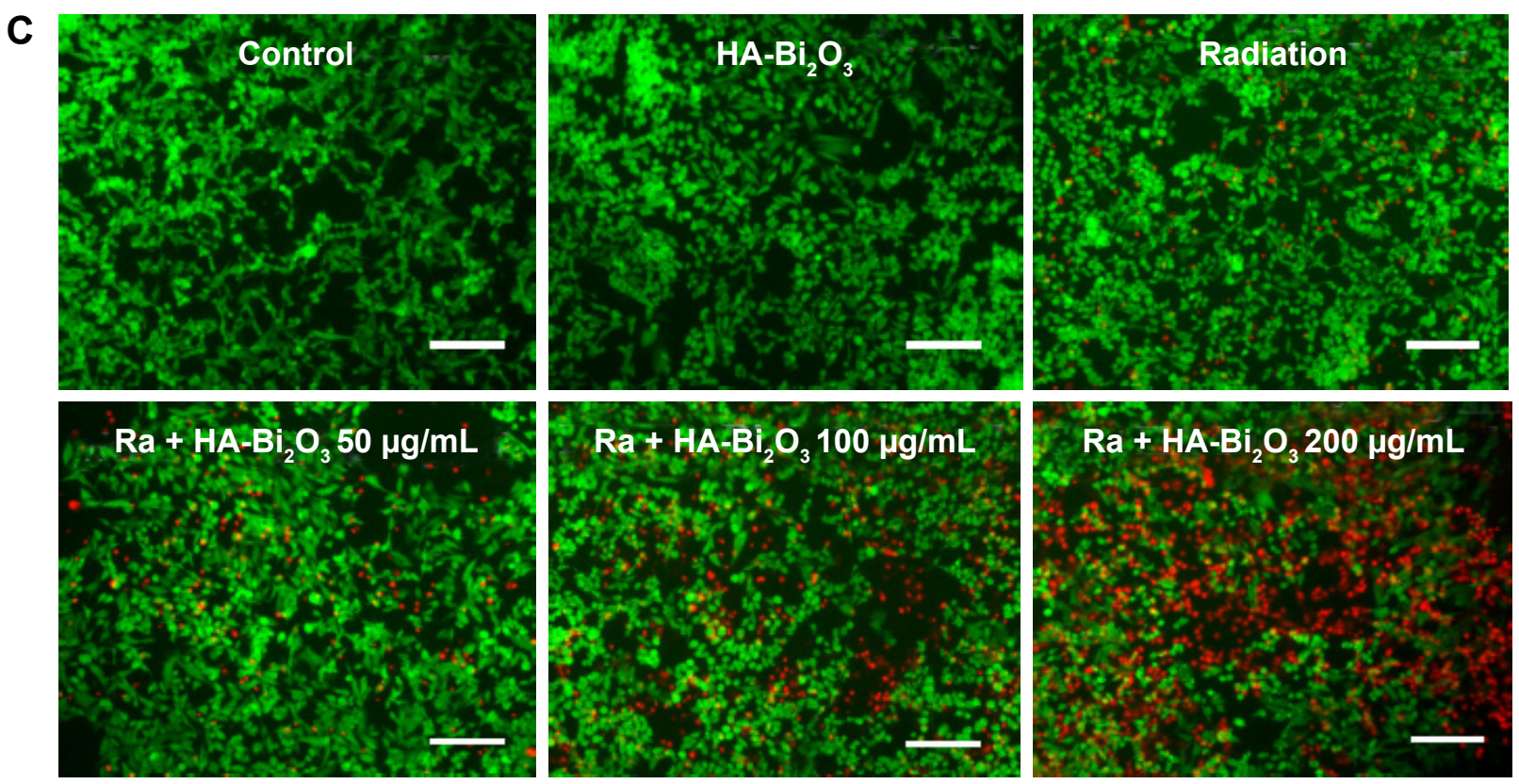

Figure 7 (A) Combined treatment of $\mathrm{HA}_{-} \mathrm{Bi}_{2} \mathrm{O}_{3}$ NPs and X-ray radiation decreased SMMC-772I cell survival detected by clonogenic assay. SMMC-772I cells were pretreated with $\mathrm{HA}_{-} \mathrm{Bi}_{2} \mathrm{O}_{3} \mathrm{NPs}$ at different concentrations for $24 \mathrm{~h}$ and then were irradiated by X-ray radiation at different dosages. (B) Colony formation of SMMC-772I cells under the combination treatment of $\mathrm{HA}_{-} \mathrm{Bi}_{2} \mathrm{O}_{3} \mathrm{NPs}$ and radiation. (C) In vitro photo thermal effect. Live-dead staining of SMMC-772I cells. SMMC-772I cells were incubated with different concentrations of $\mathrm{HA}-\mathrm{Bi}_{2} \mathrm{O}_{3} \mathrm{NPs}$ for $24 \mathrm{~h}$ and radiation. Scale bars $=200 \mu \mathrm{m}$.

Abbreviations: $\mathrm{HA}-\mathrm{Bi}_{2} \mathrm{O}_{3} \mathrm{NPs}$, hyaluronic acid-functionalized bismuth oxide nanoparticles; Ra, radiation.

NPs; $\mathrm{HA}-\mathrm{Bi}_{2} \mathrm{O}_{3}$ NPs-only treatment had no dramatic influence on the colony-forming ability of the SMMC-7721 cells, and X-ray (6 Gy) irradiation decreased the colony-forming ability of SMMC-7721 cells to 55\%. However, the treatment of $\mathrm{HA}-\mathrm{Bi}_{2} \mathrm{O}_{3} \mathrm{NPs}$ with X-ray irradiation notably inhibited cell viability by $71 \%$. The corresponding images further verified the radiosensitization of $\mathrm{HA}-\mathrm{Bi}_{2} \mathrm{O}_{3} \mathrm{NPs}$ against SMMC-7721 cells (Figure 7B).

\section{Mechanism of radiosensitization enhancement}

Flow cytometry assay and live-dead staining assay were used to further research the radiosensitization mechanism by which the combination treatment of $\mathrm{HA}-\mathrm{Bi}_{2} \mathrm{O}_{3} \mathrm{NPs}$ and X-ray radiation caused cell death. As shown in Figure $7 \mathrm{C}$, intensive green fluorescence without red fluorescence was observed in the SMMC-7721 cells treated with only $\mathrm{HA}-\mathrm{Bi}_{2} \mathrm{O}_{3} \mathrm{NPs}$ 
which verified high cell viability, but a small amount of red fluorescence was seen in the cells that received X-ray radiation treatment which indicated slight cell apoptosis. However, bright red fluorescence could be seen in the cells that received combination treatment of $\mathrm{HA}-\mathrm{Bi}_{2} \mathrm{O}_{3} \mathrm{NPs}(200 \mu \mathrm{g} / \mathrm{mL})$ and radiation (6 Gy), which demonstrated that $\mathrm{HA}-\mathrm{Bi}_{2} \mathrm{O}_{3} \mathrm{NPs}$ could dramatically cause cell apoptosis. The radiosensitization mechanism of $\mathrm{HA}-\mathrm{Bi}_{2} \mathrm{O}_{3} \mathrm{NPs}$ was further investigated using flow cytometry assay. Figures 8 and $\mathrm{S} 7$ show the flow cytometry graphs of the cells treated with $\mathrm{HA}-\mathrm{Bi}_{2} \mathrm{O}_{3}$ NPs with and without radiation. Annexin-V-EGFP emission signal was plotted on the $\mathrm{x}$-axis, while PI emission signal was plotted on the y-axis. The quantities of living cells, early apoptosis cells, and late apoptosis/necrosis cells were determined by the percentage of Annexin $\mathrm{V}^{-} / \mathrm{PI}^{-}$, Annexin $\mathrm{V}^{-} / \mathrm{PI}^{+}$, Annexin $\mathrm{V}^{+} / \mathrm{PI}^{-}$, and Annexin $\mathrm{V}^{+} / \mathrm{PI}^{+}$. Almost no apoptosis or necrosis of cells was observed in the group that received no radiation treatment with concentration up to $200 \mu \mathrm{g} / \mathrm{mL}$. When the concentration was $100 \mu \mathrm{g} / \mathrm{mL}$, after radiation, the early apoptosis rate of cells reached $30.4 \%$, while the late apoptosis/necrosis
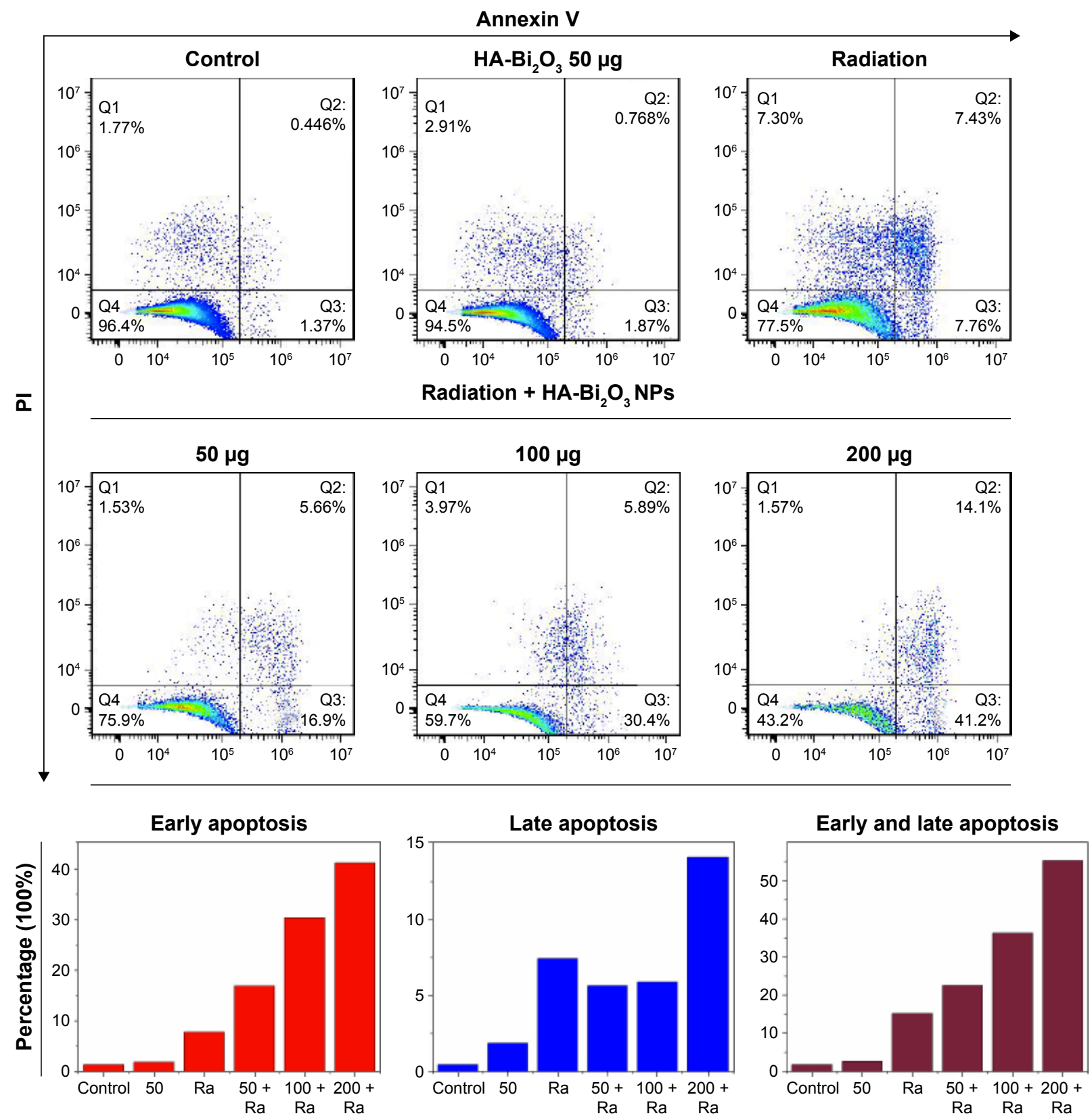

Figure 8 Flow cytometric profiles of SMMC-772I cells were examined to determine the percentages of early apoptosis and late apoptosis in cells with distinct treatments. Statistical data of percentage of early apoptosis and late apoptosis under different treatments are presented.

Abbreviations: $\mathrm{HA}-\mathrm{Bi}_{2} \mathrm{O}_{3} \mathrm{NPs}$, hyaluronic acid-functionalized bismuth oxide nanoparticles; PI, propidium iodide; Ra, radiation. 
A

DNA content
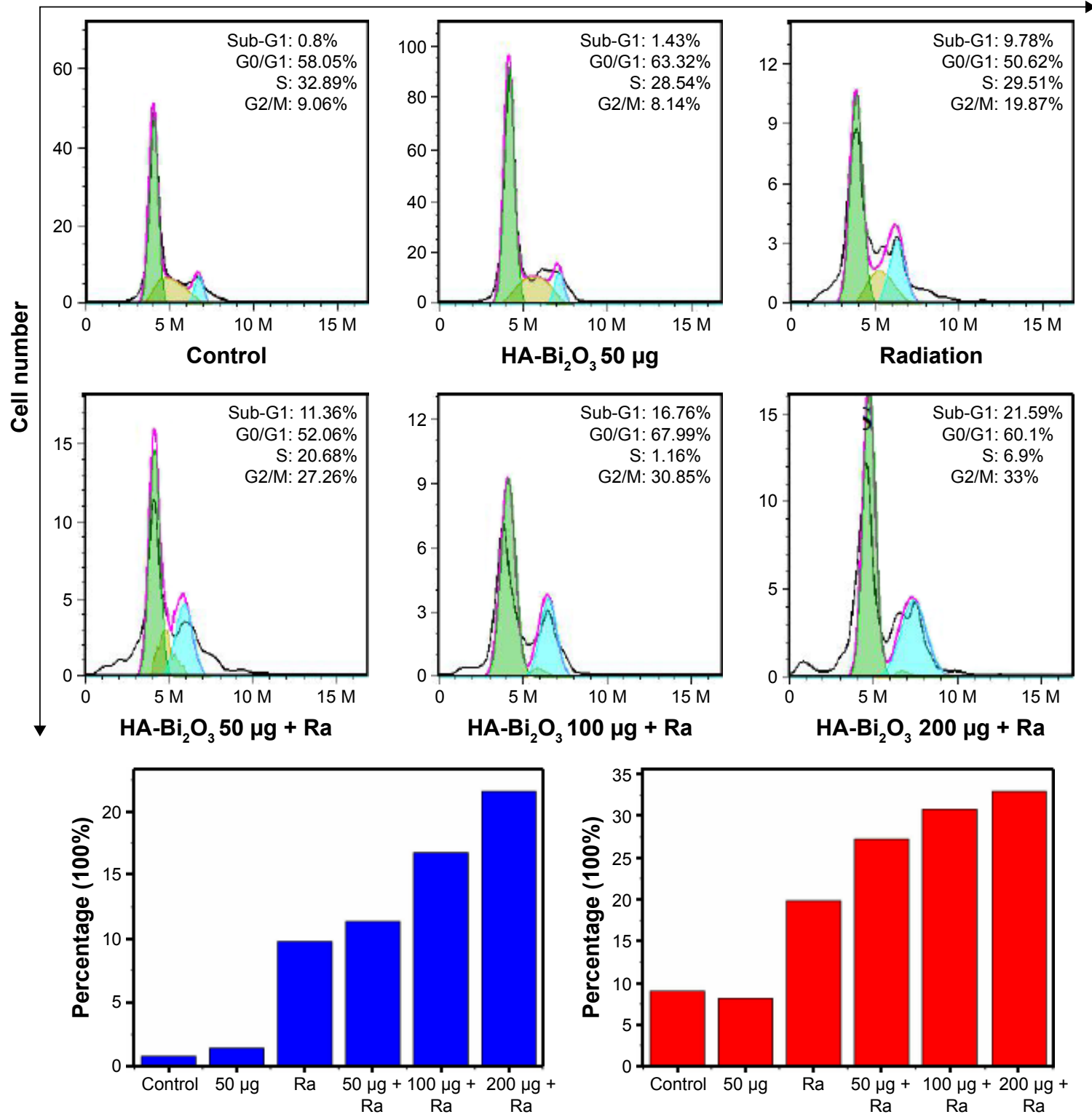

Sub-G1 phase

G2/M phase

B

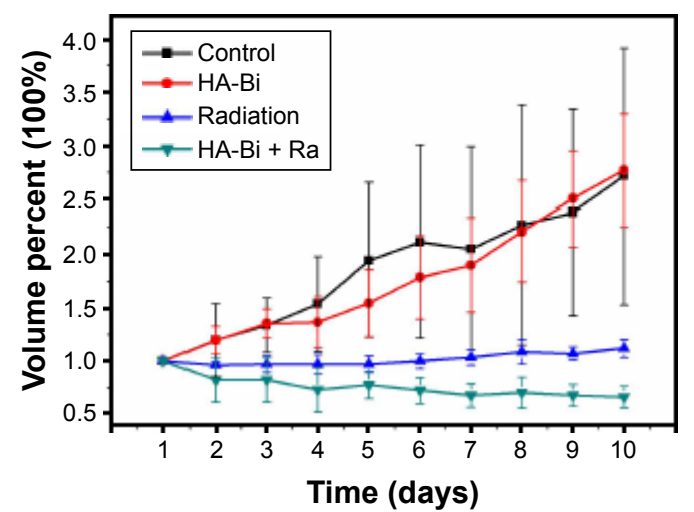

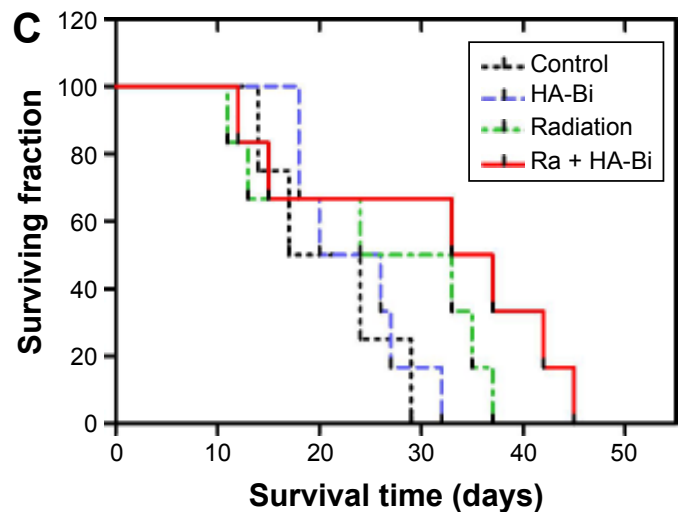

Figure 9 (A) Cell cycle analysis was performed using flow cytometry after treating with $\mathrm{HA}_{-} \mathrm{Bi}_{2} \mathrm{O}_{3} \mathrm{NPs}_{\text {and }}$ irradiation. (B) Tumor growth inhibition profiles of the mice bearing Herps tumor treated with PBS, $\mathrm{HA}-\mathrm{Bi}_{2} \mathrm{O}_{3} \mathrm{NPs}$, and radiation at the dose of $6 \mathrm{~Gy}$. (C) Kaplan-Meier survival analysis.

Abbreviations: $\mathrm{HA}_{-} \mathrm{Bi}_{2} \mathrm{O}_{3} \mathrm{NPs}$, hyaluronic acid-functionalized bismuth oxide nanoparticles; PBS, phosphate-buffered saline; Ra, radiation. 
rate was $5.89 \%$. When the concentration was $200 \mu \mathrm{g} / \mathrm{mL}$, after radiation, the early apoptosis rate of cells was $41.2 \%$, while the late apoptosis/necrosis rate reached $14.1 \%$. As analyzed by flow cytometry (Figures 9A and S8), radiation (6 Gy) alone slightly caused $19.87 \%$ of G2/M phase arrest, which might induce apoptosis of cells. ${ }^{49,50} \mathrm{In}$ addition, HA$\mathrm{Bi}_{2} \mathrm{O}_{3} \mathrm{NPs}$ (from 0 to $200 \mu \mathrm{g} / \mathrm{mL}$ ) activated apoptotic cell death from $0.446 \%$ to $2.34 \%$, as reflected by the sub-G1 proportions. ${ }^{51}$ However, the combination of $\mathrm{HA}-\mathrm{Bi}_{2} \mathrm{O}_{3} \mathrm{NPs}$ and radiation dose-dependently increased the extent of G2/M phase arrest and cell apoptosis. For instance, combination of $\mathrm{HA}-\mathrm{Bi}_{2} \mathrm{O}_{3} \mathrm{NPs}(200 \mu \mathrm{g} / \mathrm{mL})$ and radiation at $6 \mathrm{~Gy}$ enhanced the proportions of $\mathrm{G} 2 / \mathrm{M}$ phase arrest and sub-G1 peak to $33 \%$ and $21.59 \%$, respectively, which indicated that $\mathrm{HA}-\mathrm{Bi}_{2} \mathrm{O}_{3}$ NPs could be an efficient alternative to improve radiosensitization enhancements for radiotherapy and have great promising applications in radiotherapy of tumors.

Generally, the combination of $\mathrm{HA}-\mathrm{Bi}_{2} \mathrm{O}_{3} \mathrm{NPs}$ and X-ray irradiation exhibited a synergistic effect on the decline of cell colony formation and the cell viability in a dose-dependent manner; radiosensitization enhancement effect on the basis of flow cytometry and live-dead staining corroborated that $\mathrm{HA}-\mathrm{Bi}_{2} \mathrm{O}_{3}$ NPs could be an efficient alternative to improve radiosensitization enhancement for radiotherapy. The flow cytometry data revealed that cells upon X-ray irradiation treatment assisted by $\mathrm{HA}-\mathrm{Bi}_{2} \mathrm{O}_{3} \mathrm{NPs}$ showed irreversible damage, and the cells could no longer function or recover from the damage.

\section{Radiosensitization of $\mathrm{HA}-\mathrm{Bi}_{2} \mathrm{O}_{3} \mathrm{NPs}$ in vivo}

To specifically examine whether the therapeutic effects of $\mathrm{HA}-\mathrm{Bi}_{2} \mathrm{O}_{3}$ NPs can enable overcoming the inherent radioresistance of cancer cells in vivo, ICR mice bearing $100-\mathrm{mm}^{3}$ subcutaneous Herps flank tumors were divided into four groups ( $n=6$ per group). Notably, contrast enhancement was visible within the tumors of mice that received $\mathrm{HA}-\mathrm{Bi}_{2} \mathrm{O}_{3} \mathrm{NPs}$, which enabled CT-guided stereoscopic radiation (Figure S9). The tumor volumes of each group were measured and plotted as a function of time (Figures 9B and S10). The control group (PBS) and the group that received $\mathrm{HA}-\mathrm{Bi}_{2} \mathrm{O}_{3}$ NPs alone exhibited 2.5- to 3.0-fold increases in tumor volumes, respectively, compared to their original volumes, indicating that the $\mathrm{HA}-\mathrm{Bi}_{2} \mathrm{O}_{3}$ NPs had no influence on the tumor growth. The group that received $\mathrm{HA}-\mathrm{Bi}_{2} \mathrm{O}_{3} \mathrm{NPs}$ without radiation also exhibited similar tumor growth as control group, indicating that $\mathrm{HA}-\mathrm{Bi}_{2} \mathrm{O}_{3} \mathrm{NPs}$ are nontoxic without irradiation. Most importantly, $\mathrm{HA}-\mathrm{Bi}_{2} \mathrm{O}_{3} \mathrm{NPs}$ exhibited significant damage on the tumors upon radiation, which quickly gave rise to tumor necrosis 2 days postinjection and subsequent complete tumor ablation without any regrowth during 10 days postinjection, which accords with the enhanced in vitro cytotoxicity. However, the control group that received only radiation exhibited tumor regrowth 3 days postinjection, and finally increase in tumor volumes during 4-10 days postinjection. The survival time $^{52}$ (Figure 9C) was measured from the time of injecting ascites subcutaneously at $\mathrm{SSD}$. Mice that received $\mathrm{HA}-\mathrm{Bi}_{2} \mathrm{O}_{3}$ NPs prior to radiation therapy exhibited a statistically significant $(P<0.05)$ improvement in median survival (35 days), compared to mice treated with radiation alone (24 days). Obviously, the group treated with $\mathrm{HA}-\mathrm{Bi}_{2} \mathrm{O}_{3}$ NPs exhibited more significant damage, which may be ascribed to their absorbing high-energy photons and emission of secondary electrons and Auger electrons. Moreover, deep penetration and uniform distribution of $\mathrm{HA}-\mathrm{Bi}_{2} \mathrm{O}_{3} \mathrm{NPs}$ in tumor could also facilitate complete tumor destruction, contributing to eradication of residual cancer cells.

\section{Conclusion}

In summary, we developed bifunctional $\mathrm{Bi}_{2} \mathrm{O}_{3} \mathrm{NPs}$ for effective CT imaging and radiosensitization of tumor by HA functionalization. On coating with $\mathrm{HA}$, the as-prepared $\mathrm{HA}-\mathrm{Bi}_{2} \mathrm{O}_{3}$ NPs enabled realizing the feasibility of specific targeting to cancer cells overexpressing CD44 receptors. The $\mathrm{HA}-\mathrm{Bi}_{2} \mathrm{O}_{3}$ NPs revealed favorable solubility in water and excellent biocompatibility confirming its series of biological and chemical effects. Furthermore, the heavy metal-based $\mathrm{HA}-\mathrm{Bi}_{2} \mathrm{O}_{3} \mathrm{NPs}$ could be effectively excreted throughout the renal clearance, reflecting low toxicity. The resultant $\mathrm{HA}-\mathrm{Bi}_{2} \mathrm{O}_{3} \mathrm{NPs}$ encapsulated with $\mathrm{Bi}$ atoms not only excellently overcame the inherent radioresistance of cancer cells by absorbing the high-energy photons and emitting secondary electrons and Auger electrons but also possessed high X-ray attenuation coefficient in favor of CT imaging-guided radiotherapy with a significant radiosensitization enhancement. Thus, the novel $\mathrm{HA}-\mathrm{Bi}_{2} \mathrm{O}_{3} \mathrm{NPs}$ have great promising applications in diagnosis and radiotherapy of tumors.

\section{Acknowledgments}

This research was supported by the National Natural Science Foundation of China (81301316 and 31200676), China Postdoctoral Science Foundation (2013M540425, 2014T70487 and 2015M571705), Health and Family Planning Commission of Jiangsu Province scientific research subject 
(H201557), Natural Science Foundation of Jiangsu Province (BK20161317), and Senior Talents Scientific Research Foundation of Jiangsu University (13JDG022 and 11JDG113).

\section{Disclosure}

The authors report no conflicts of interest in this work.

\section{References}

1. Huang Y, Luo Y, Zheng W, Chen T. Rational design of cancer-targeted BSA protein nanoparticles as radiosensitizer to overcome cancer radioresistance. ACS Appl Mater Interfaces. 2014;6(21):19217-19228.

2. Lord CJ, Ashworth A. The DNA damage response and cancer therapy. Nature. 2012;481(7381):287-294.

3. Fan W, Shen B, Bu W, et al. Rattle-structured multifunctional nanotheranostics for synergetic chemo-/radiotherapy and simultaneous magnetic/ luminescent dual-mode imaging. J Am Chem Soc. 2013;135(17): 6494-6503.

4. Pan Y, Zhang Q, Atsaves V, Yang H, Claret FX. Suppression of Jab1/CSN5 induces radio- and chemo-sensitivity in nasopharyngeal carcinoma through changes to the DNA damage and repair pathways. Oncogene. 2013;32(22):2756-2766.

5. Xing $\mathrm{H}$, Zheng $\mathrm{X}$, Ren $\mathrm{Q}$, et al. Computed tomography imaging-guided radiotherapy by targeting upconversion nanocubes with significant imaging and radiosensitization enhancements. Sci Rep. 2013;3:1751.

6. Liu Y, Zhang N. Gadolinium loaded nanoparticles in theranostic magnetic resonance imaging. Biomaterials. 2012;33(21):5363-5375.

7. Luo Z, Ding X, Hu Y, et al. Engineering a hollow nanocontainer platform with multifunctional molecular machines for tumor-targeted therapy in vitro and in vivo. ACS Nano. 2013;7(11):10271-10284.

8. Kakuta T, Takashima Y, Nakahata M, Otsubo M, Yamaguchi H, Harada A. Preorganized hydrogel: self-healing properties of supramolecular hydrogels formed by polymerization of host-guest-monomers that contain cyclodextrins and hydrophobic guest groups. Adv Mater. 2013;25(20):2849-2853.

9. Peng L, Peng X, Liu B, Wu C, Xie Y, Yu G. Ultrathin two-dimensional $\mathrm{MnO}_{2}$ /graphene hybrid nanostructures for high-performance, flexible planar supercapacitors. Nano Lett. 2013;13(5):2151-2157.

10. Caracciolo G, Cardarelli F, Pozzi D, et al. Selective targeting capability acquired with a protein corona adsorbed on the surface of 1,2-dioleoyl3-trimethylammonium propane/DNA nanoparticles. ACS Appl Mater Interfaces. 2013;5(24):13171-13179.

11. Taratula O, Kuzmov A, Shah M, Garbuzenko OB, Minko T. Nanostructured lipid carriers as multifunctional nanomedicine platform for pulmonary co-delivery of anticancer drugs and siRNA. J Control Release. 2013;171(3):349-357.

12. Park S, Kang S, Chen X, et al. Tumor suppression via paclitaxel-loaded drug carriers that target inflammation marker upregulated in tumor vasculature and macrophages. Biomaterials. 2013;34(2):598-605.

13. Shilo M, Reuveni T, Motiei M, Popovtzer R. Nanoparticles as computed tomography contrast agents: current status and future perspectives. Nanomedicine (Lond). 2012;7(2):257-269.

14. Luchette M, Korideck H, Makrigiorgos M, Tillement O, Berbeco R. Radiation dose enhancement of gadolinium-based AGuIX nanoparticles on HeLa cells. Nanomedicine. 2014;10(8):1751-1755.

15. Le DG, Miladi I, Alric C, et al. Toward an image-guided microbeam radiation therapy using gadolinium-based nanoparticles. ACS Nano. 2011; 5(12):9566-9574.

16. Dufort S, Bianchi A, Henry M, et al. Nebulized gadolinium-based nanoparticles: a theranostic approach for lung tumor imaging and radiosensitization. Small. 2015;11(2):215-221.

17. Xing $\mathrm{H}, \mathrm{Bu} \mathrm{W}$, Zhang $\mathrm{S}$, et al. Multifunctional nanoprobes for upconversion fluorescence, MR and CT trimodal imaging. Biomaterials. 2012;33(4):1079-1089.
18. Ma M, Huang Y, Chen H, et al. Bi2S3-embedded mesoporous silica nanoparticles for efficient drug delivery and interstitial radiotherapy sensitization. Biomaterials. 2015;37:447-455.

19. Zhang M, Ju H, Zhang L, et al. Engineering iodine-doped carbon dots as dual-modal probes for fluorescence and X-ray CT imaging. Int $J$ Nanomedicine. 2015;10:6943-6953.

20. Chen J, Yang XQ, Qin MY, Zhang XS, Xuan Y, Zhao YD. Hybrid nanoprobes of bismuth sulfide nanoparticles and $\mathrm{CdSe} / \mathrm{ZnS}$ quantum dots for mouse computed tomography/fluorescence dual mode imaging. J Nanobiotechnology. 2015;13:76.

21. Chen J, Yang XQ, Meng YZ, et al. In vitro and in vivo CT imaging using bismuth sulfide modified with a highly biocompatible Pluronic F127. Nanotechnology. 2014;25(29):295103.

22. Rivera EJ, Tran LA, Hernández-Rivera M, et al. Bismuth@US-tubes as a potential contrast agent for X-ray imaging applications. J Mater Chem B Mater Biol Med. 2013;1(37):10.1039/C3TB20742K.

23. Li Z, Hu Y, Howard KA, et al. Multifunctional bismuth selenide nanocomposites for antitumor thermo-chemotherapy and imaging. ACS Nano. 2016;10(1):984-997.

24. Grigas J, Talik E, Lazauskas V. X-ray photoelectron spectra and electronic structure of Bi2S3 crystals. Phys Status Solidi. 2002;232(2): 220-230.

25. Thomson JW, Lawson G, O'Brien P, et al. Flash nano-welding: investigation and control of the photothermal response of ultrathin bismuth sulfide nanowire films. Adv Mater. 2010;22(39):4395-4400.

26. Martinez L, Bernechea M, de Arquer F, Konstantatos G. Near IRsensitive, non-toxic polymer/nanocrystal solar cells employing Bi2S3 as the electron acceptor. Adv Energy Mater. 2011;1(6):1029-1035.

27. Malakooti R, Cademartiri L, Akçakir Y, Petrov S, Migliori A, Ozin GA. Shape-controlled $\mathrm{Bi}_{2} \mathrm{~S}_{3}$ nanocrystals and their plasma polymerization into flexible films. Adv Mater. 2006;18(16):2189-2194.

28. Sigman MB, Korgel BA. Solventless synthesis of $\mathrm{Bi}_{2} \mathrm{~S}_{3}$ (bismuthinite) nanorods, nanowires, and nanofabric. Chem Mater. 2005;17(7): $1655-1660$.

29. Yao MH, Ma M, Chen Y, et al. Multifunctional $\mathrm{Bi}_{2} \mathrm{~S}_{3} /$ PLGA nanocapsule for combined HIFU/radiation therapy. Biomaterials. 2014;35(28): $8197-8205$.

30. Alqathami M, Blencowe A, Yeo UJ, et al. Enhancement of radiation effects by bismuth oxide nanoparticles for kilovoltage $\mathrm{x}$-ray beams: a dosimetric study using a novel multi-compartment $3 \mathrm{D}$ radiochromic dosimeter. J Phys. 2013;44(1):012025.

31. Preihs C, Arambula JF, Lynch VM, Siddik ZH, Sessler JL. Bismuthand lead-texaphyrin complexes: towards potential $\alpha$-core emitters for radiotherapy. Chem Commun (Camb). 2010;46(42):7900-7902.

32. Goh EJ, Kim KS, Kim YR, et al. Bioimaging of hyaluronic acid derivatives using nanosized carbon dots. Biomacromolecules. 2012; 13(8):2554-2561.

33. Lee MY, Yang JA, Jung HS, et al. Hyaluronic acid-gold nanoparticle/ interferon $\alpha$ complex for targeted treatment of hepatitis $\mathrm{C}$ virus infection. ACS Nano. 2012;6(11):9522-9531.

34. Abdullah-Al-Nahain, Lee JE, In I, et al. Target delivery and cell imaging using hyaluronic acid-functionalized graphene quantum dots. Mol Pharm. 2013;10(10):3736-3744.

35. Petoral Jr RM, Söderlind F, Klasson A, et al. Synthesis and characterization of $\mathrm{Tb}^{3+}$-doped $\mathrm{Gd}_{2} \mathrm{O}_{3}$ nanocrystals: a bifunctional material with combined fluorescent labeling and MRI contrast agent properties. J Phys Chem. 2009;113(17):6913-6920.

36. Zhang M, Zhao X, Fang Z, et al. Fabrication of HA/PEI-functionalized carbon dots for tumor targeting, intracellular imaging and gene delivery. RSC Adv. 2017;7(6):3369-3375.

37. Zhang M, Fang Z, Zhao X, et al. Hyaluronic acid functionalized nitrogen-doped carbon quantum dots for targeted specific bioimaging. RSC Adv. 2016;6(107):104979-104984.

38. Du F, Yuan J, Zhang M, et al. Facile synthesis of biocompatible nitrogen-doped carbon dots for bioimaging. RSC Adv. 2014;4(71): 37536-37541. 
39. Li J, Zheng L, Cai H, et al. Polyethyleneimine-mediated synthesis of folic acid-targeted iron oxide nanoparticles for in vivo tumor MR imaging. Biomaterials. 2013;34(33):8382-8392.

40. Du F, Zhang L, Zhang L, et al. Engineered gadolinium-doped carbon dots for magnetic resonance imaging-guided radiotherapy of tumors. Biomaterials. 2017;121:109-120.

41. Huang $\mathrm{Y}$, Wang $\mathrm{W}$, Zhang Q, et al. In situ fabrication of $\alpha-\mathrm{Bi}_{2} \mathrm{O}_{3} /$ $(\mathrm{BiO})_{2} \mathrm{CO}_{3}$ nanoplate heterojunctions with tunable optical property and photocatalytic activity. Sci Rep. 2016;6:23435.

42. Wang Y, Yang T, Ke H, et al. Smart albumin-biomineralized nanocomposites for multimodal imaging and photothermal tumor ablation. $A d v$ Mater. 2015;27(26):3874-3882.

43. Du F, Li J, Hua Y, et al. Multicolor nitrogen-doped carbon dots for live cell imaging. J Biomed Nanotechnol. 2015;11(5):780-788.

44. Nami B, Donmez H, Koçak N. Autophagy reduces subpopulation of $\mathrm{CD}^{44+} / \mathrm{CD}^{24} /$ low phenotype cancer stem cells in MCF7 and Hep-2 cells culture. Stem Cell Res. 2015;(3):e1002.

45. Yu GF, Chen YM, Yan YH, Zeng WT, Zhu KL. Effect of arsenic trioxide on invasion and metastasis of human hepatocarcinoma cells SMMC-7721 in vitro. J Mod Oncol. 2011;7(19):1282-1284.
46. Wang J, Chen H, Ji H, Zhang ZG. Effect of earthworm fibrinolytic enzyme on growth of xenografted tumor of hepatocellular carcinoma (HCC) and expression of CD44v6. Cancer Res Prev Treat. 2009;36(5):375-379.

47. Al Zaki A, Joh D, Cheng Z, et al. Gold-loaded polymeric micelles for computed tomography-guided radiation therapy treatment and radiosensitization. ACS Nano. 2014;8(1):104-112.

48. Dong K, Ju E, Liu J, Han X, Ren J, Qu X. Ultrasmall biomoleculeanchored hybrid $\mathrm{GdVO}_{4}$ nanophosphors as a metabolizable multimodal bioimaging contrast agent. Nanoscale. 2014;6(20):12042-12049.

49. Campisi J, d'Adda di Fagagna F. Cellular senescence: when bad things happen to good cells. Nat Rev Mol Cell Biol. 2007;8(9):729-740.

50. Rao PC, Begum S, Sahai M, Sriram DS. Coptisine-induced cell cycle arrest at $\mathrm{G} 2 / \mathrm{M}$ phase and reactive oxygen species-dependent mitochondria-mediated apoptosis in non-small-cell lung cancer A549 cells. Tumour Biol. 2017;39(3):1010428317694565.

51. Liu DX, Greene LA. Neuronal apoptosis at the G1/S cell cycle checkpoint. Cell Tissue Res. 2001;305(2):217-228.

52. Liu J, Guo B, Chen Z, et al. miR-125b promotes MLL-AF9-driven murine acute myeloid leukemia involving a VEGFA-mediated noncell-intrinsic mechanism. Blood. 2017;129(11):1491-1502. 


\section{Supplementary materials}

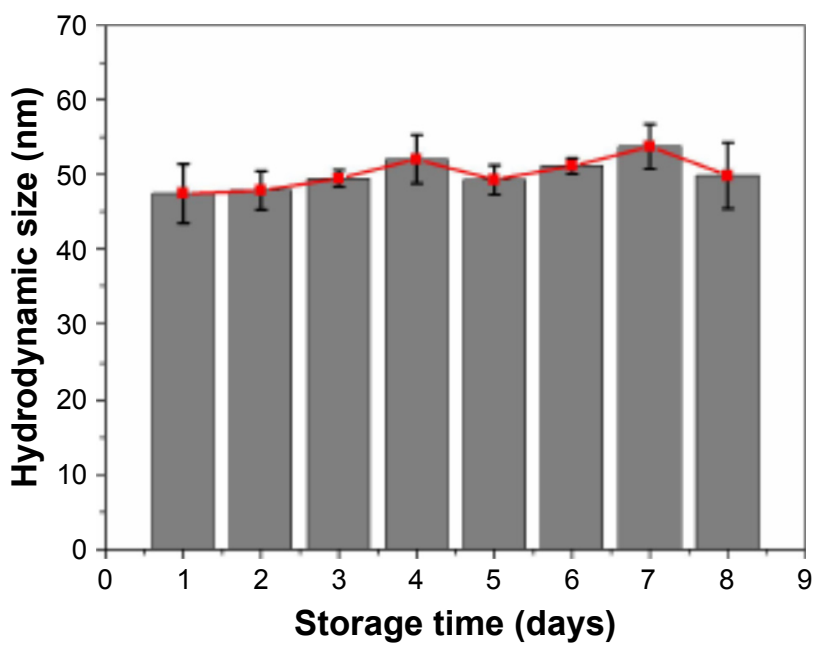

Figure SI Hydrodynamic diameter of $\mathrm{HA}-\mathrm{Bi}_{2} \mathrm{O}_{3} \mathrm{NPs}$ in $90 \%$ PBS with $10 \% \mathrm{FBS}$ during 8 days of storage.

Abbreviations: $\mathrm{HA}-\mathrm{Bi}_{2} \mathrm{O}_{3}$ NPs, hyaluronic acid-functionalized bismuth oxide nanoparticles; PBS, phosphate-buffered saline.

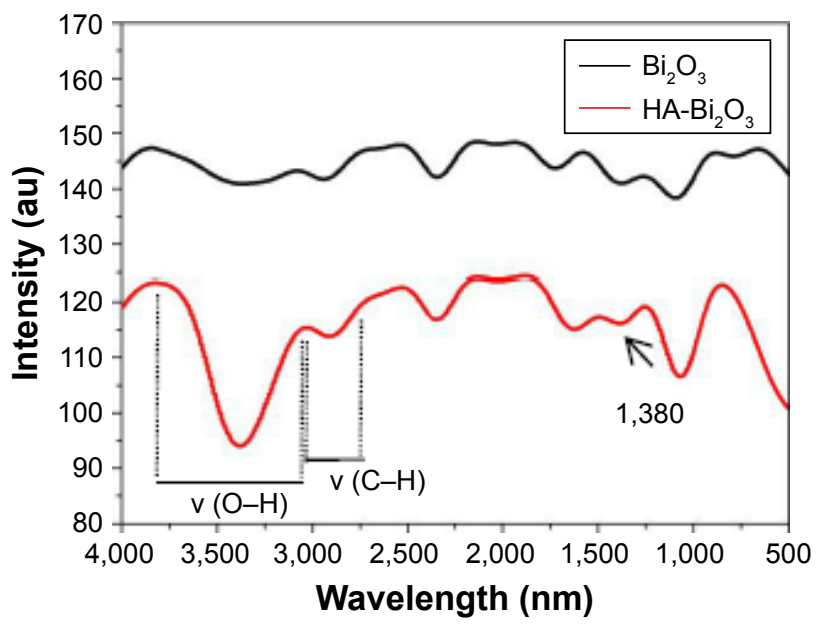

Figure S2 FT-IR spectrum of $\mathrm{HA}-\mathrm{Bi}_{2} \mathrm{O}_{3} \mathrm{NPs}$ and naked $\mathrm{Bi}_{2} \mathrm{O}_{3} \mathrm{NPs}$.

Abbreviations: FT-IR, Fourier transform infrared; $\mathrm{HA}-\mathrm{Bi}_{2} \mathrm{O}_{3} \mathrm{NPs}$, hyaluronic acidfunctionalized $\mathrm{Bi}_{2} \mathrm{O}_{3} \mathrm{NPs} ; \mathrm{Bi}_{2} \mathrm{O}_{3} \mathrm{NPs}$, bismuth oxide nanoparticles.

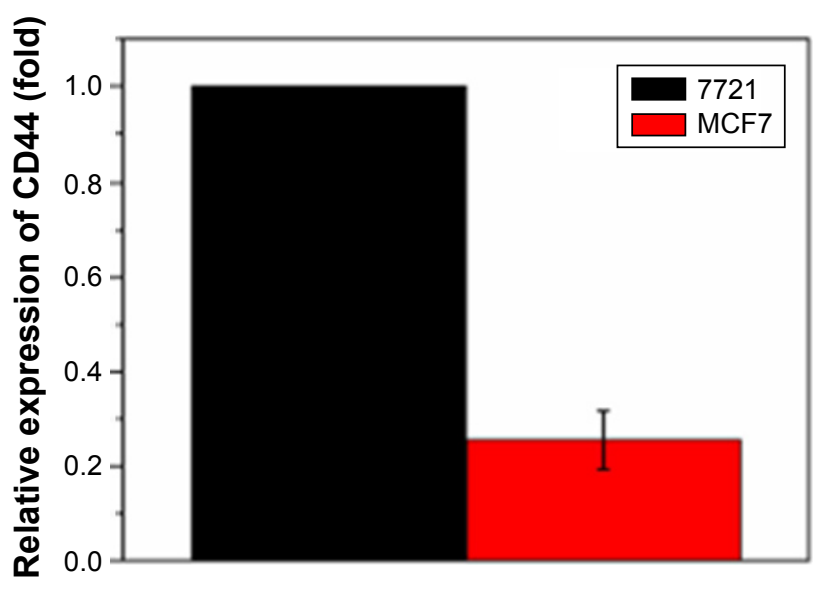

Figure S3 CD44 expression determined by real-time PCR in distinct cancer cells. Abbreviation: PCR, polymerase chain reaction.

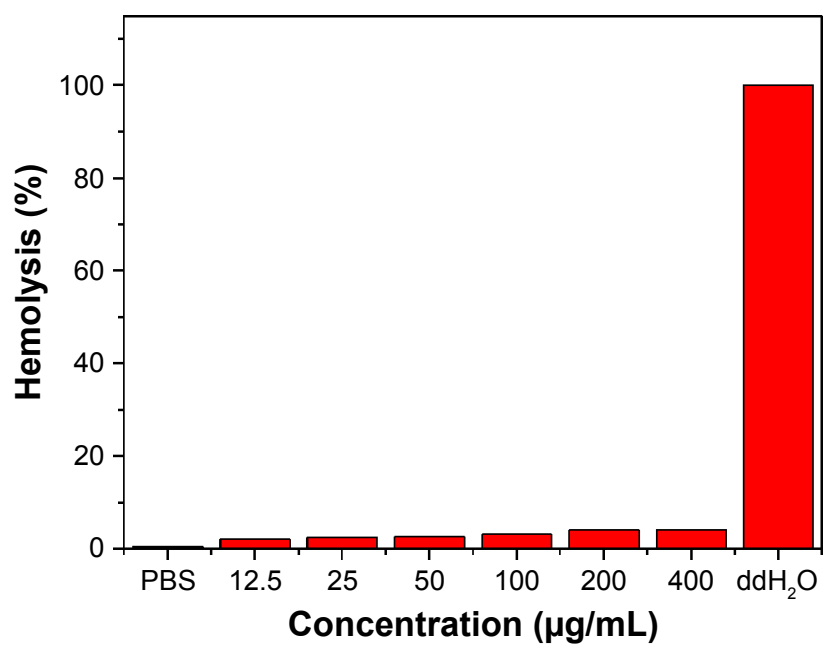

Figure S4 Concentration-hemolysis relation in hemolysis assay.

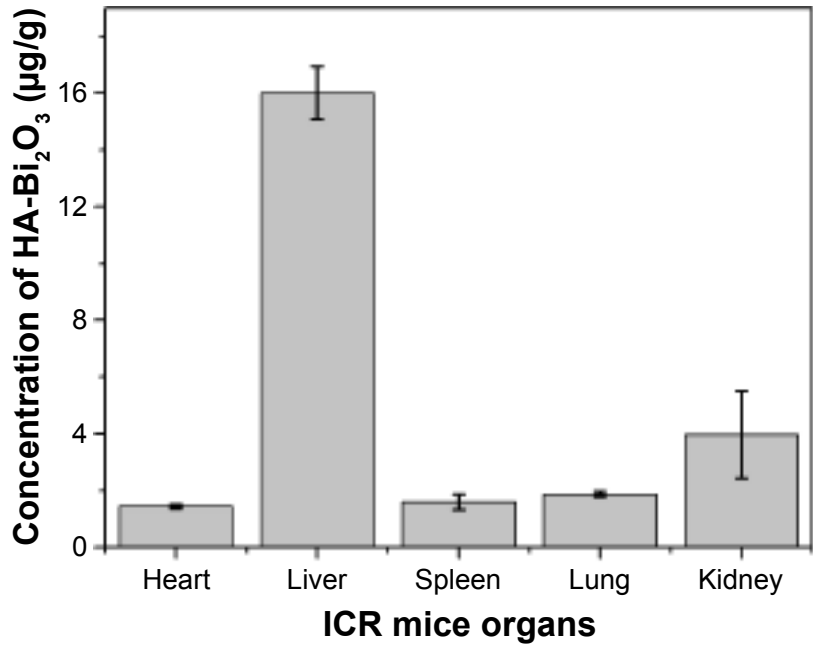

Figure S5 Distribution of $\mathrm{Bi}$ element from various normal tissues at $24 \mathrm{~h}$ postinjection of $\mathrm{HA}-\mathrm{Bi}_{2} \mathrm{O}_{3} \mathrm{NPs}$ at the dose of $40 \mathrm{mg} / \mathrm{kg}$.

Abbreviation: $\mathrm{HA}_{-} \mathrm{Bi}_{2} \mathrm{O}_{3} \mathrm{NPs}$, hyaluronic acid-functionalized bismuth oxide nanoparticles.

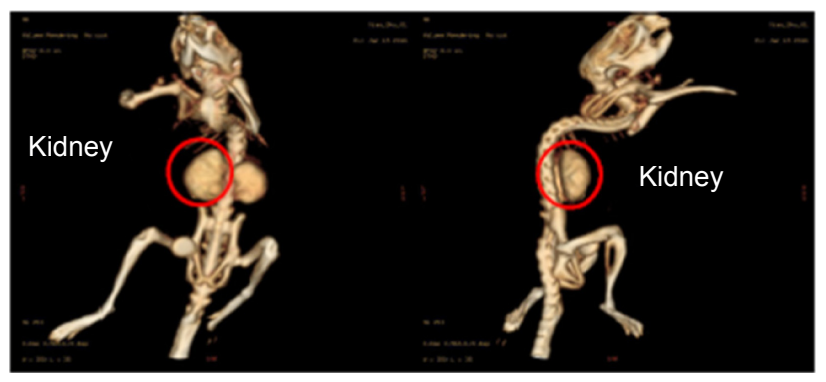

Figure S6 In vivo three-dimensional volume rendering and transverse slice CT images.

Note: Circles represent the designated area

Abbreviation: CT, computed tomography. 

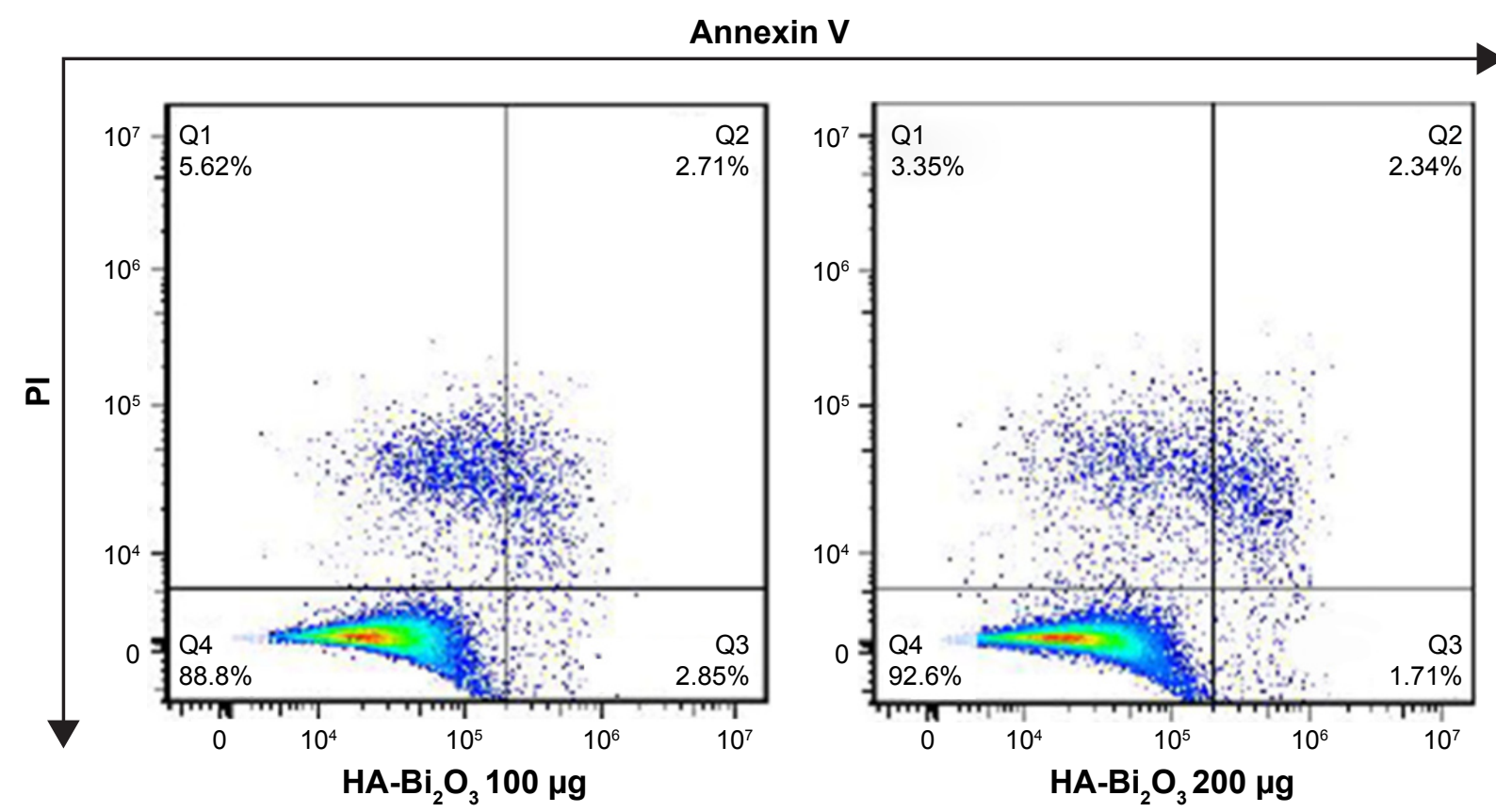

Figure S7 Flow cytometric profiles of SMMC-772I cells were examined to determine the percentages of early apoptosis and late apoptosis cells with different concentrations of $\mathrm{HA}-\mathrm{Bi}_{2} \mathrm{O}_{3} \mathrm{NPs}$.

Abbreviations: $\mathrm{HA}-\mathrm{Bi}_{2} \mathrm{O}_{3} \mathrm{NPs}$, hyaluronic acid-functionalized bismuth oxide nanoparticles; Pl, propidium iodide.
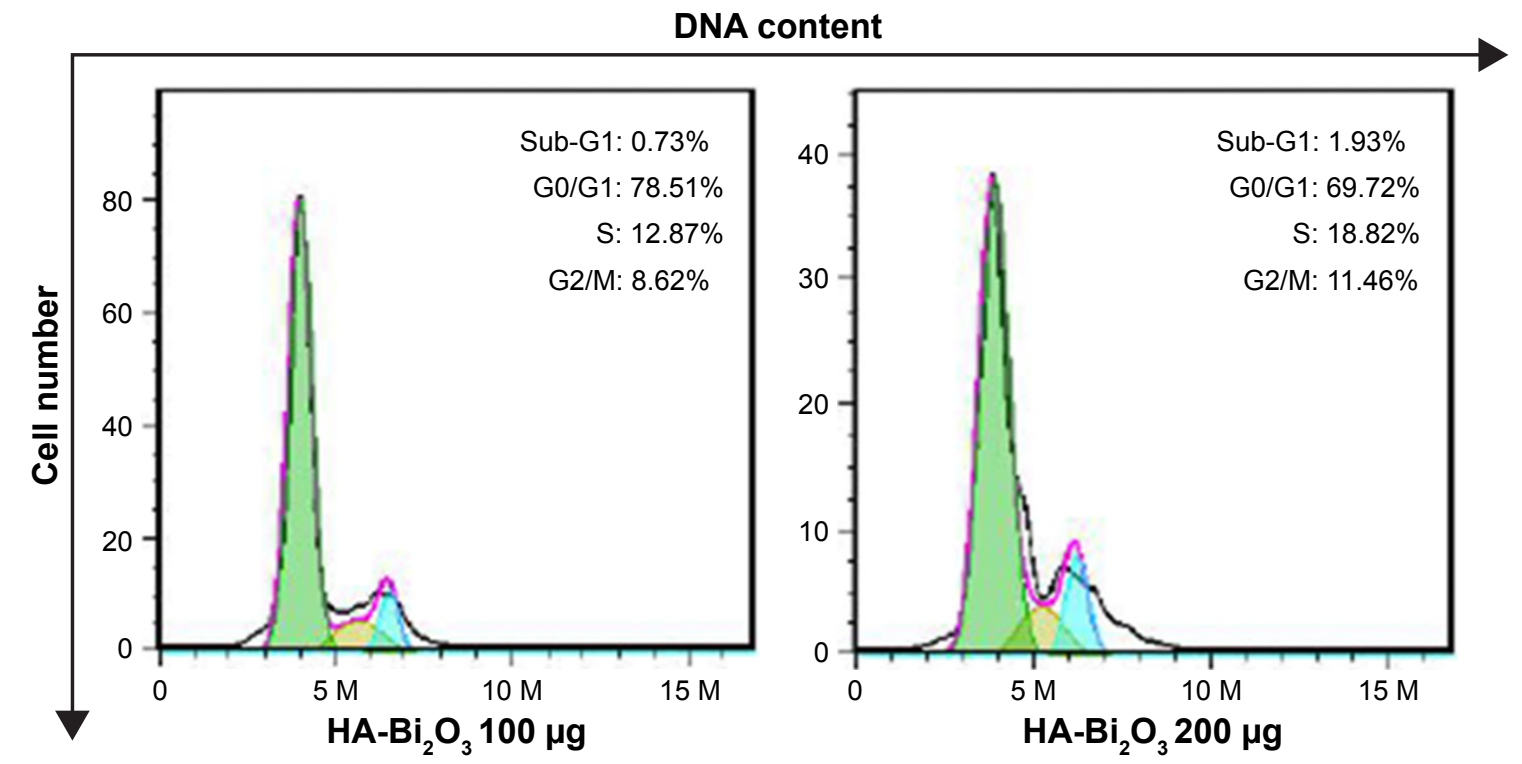

Figure S8 Flow cytometric profiles of SMMC-772I cells were examined to determine the G2/M phase arrest and apoptosis with different concentrations of HA$\mathrm{Bi}_{2} \mathrm{O}_{3} \mathrm{NPs}$.

Abbreviation: $\mathrm{HA}-\mathrm{Bi}_{2} \mathrm{O}_{3} \mathrm{NPs}$, hyaluronic acid-functionalized bismuth oxide nanoparticles. 


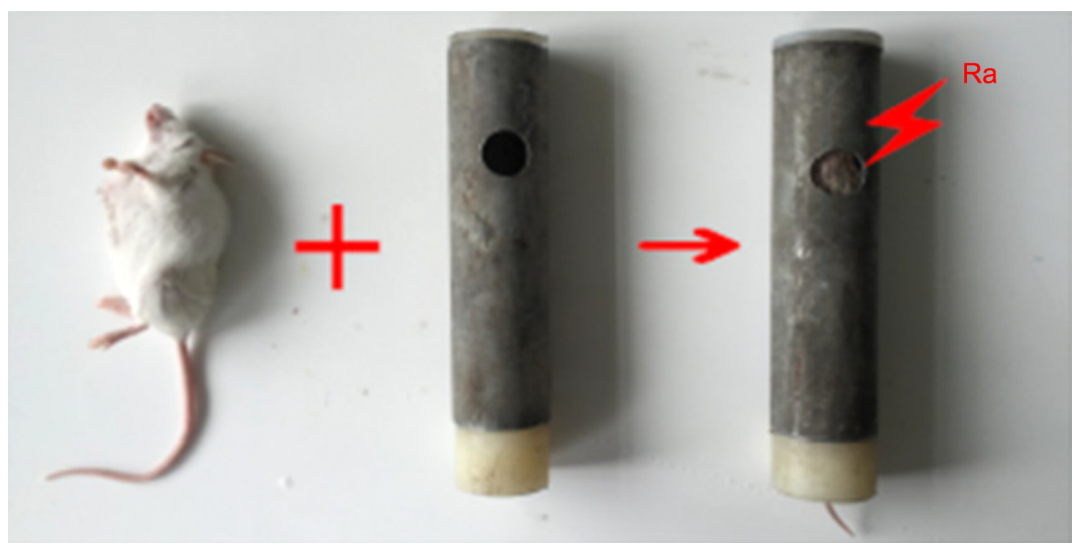

Figure S9 Self-prepared device for mice radiotherapy.

Note: The mice were placed in a leaden device which exposed parts of the subcutaneous tumor to radiation treatment.

Abbreviation: Ra, radiation.

A

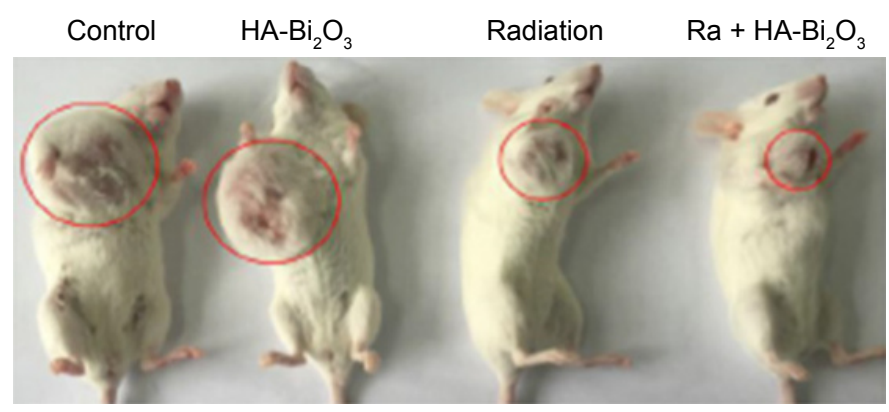

B

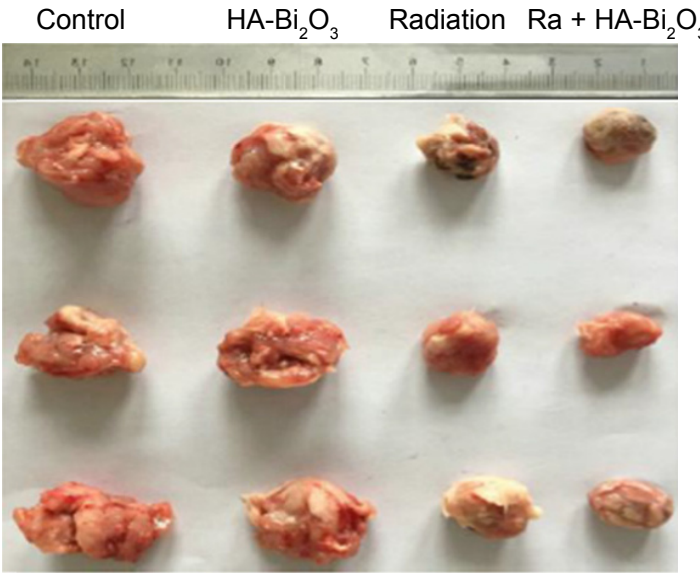

Figure SIO Photographs of the tumors extracted from the mice bearing Herps tumor at the end of the radiation experiment.

Notes: (A) Scope of subcutaneous tumors (red circles). (B) The subcutaneous tumors were recovered from the mice with three replications.

Abbreviations: $\mathrm{HA}-\mathrm{Bi}_{2} \mathrm{O}_{3} \mathrm{NPs}$, hyaluronic acid-functionalized bismuth oxide nanoparticles; Ra, radiation.

International Journal of Nanomedicine

\section{Publish your work in this journal}

The International Journal of Nanomedicine is an international, peerreviewed journal focusing on the application of nanotechnology in diagnostics, therapeutics, and drug delivery systems throughout the biomedical field. This journal is indexed on PubMed Central, MedLine, CAS, SciSearch ${ }^{\circledR}$, Current Contents $₫ /$ Clinical Medicine,

\section{Dovepress}

Journal Citation Reports/Science Edition, EMBase, Scopus and the Elsevier Bibliographic databases. The manuscript management system is completely online and includes a very quick and fair peer-review system, which is all easy to use. Visit http://www.dovepress.com/ testimonials.php to read real quotes from published authors. 